\title{
Moment tensor inversion of the 2016 southeast offshore Mie earthquake in the Tonankai region using a three-dimensional velocity structure model: effects of the accretionary prism and subducting oceanic plate
}

\author{
Shunsuke Takemura* (10, Takeshi Kimura, Tatsuhiko Saito, Hisahiko Kubo and Katsuhiko Shiomi
}

\begin{abstract}
The southeast offshore Mie earthquake occurred on April 1, 2016 near the rupture area of the 1944 Tonankai earthquake, where seismicity around the interface of the Philippine Sea plate had been very low until this earthquake. Since this earthquake occurred outside of seismic arrays, the focal mechanism and depth were not precisely constrained using a one-dimensional velocity model, as in a conventional approach. We conducted a moment tensor inversion of this earthquake by using a three-dimensional velocity structure model. Before the analysis of observed data, we investigated the effects of offshore heterogeneous structures such as the seawater, accretionary prism, and subducting oceanic plate by using synthetic seismograms in a full three-dimensional model and simpler models. The accretionary prism and subducting oceanic plate play important roles in the moment tensor inversion for offshore earthquakes in the subduction zone. Particularly, the accretionary prism, which controls the excitation and propagation of long-period surface waves around the offshore region, provides better estimations of the centroid depths and focal mechanisms of earthquakes around the Nankai subduction zone. The result of moment tensor inversion for the 2016 southeast offshore Mie earthquake revealed low-angle thrust faulting with a moment magnitude of 5.6. According to geophysical surveys in the Nankai Trough, our results suggest that the rupture of this earthquake occurred on the interface of the Philippine Sea plate, rather than on a mega-splay fault. Detailed comparisons of first-motion polarizations provided additional constraints of the rupture that occurred on the interface of the Philippine Sea plate.
\end{abstract}

Keywords: Focal mechanism, Moment tensor inversion, Nankai Trough, Accretionary prism, Philippine Sea plate, Finite-difference method

\section{Introduction}

Along the Nankai Trough, Japan (Fig. 1), the Philippine Sea plate (PHS) is subducting beneath southwestern Japan at a rate of 2-6 cm per year (e.g., Heki and Miyazaki 2001; Seno et al. 1993). The slip deficits due to the PHS subduction have been widely detected (e.g.,

\footnotetext{
*Correspondence: shunsuke@bosai.go.jp

National Research Institute for Earth Science and Disaster Resilience, 3-1

Tennodai, Tsukuba, Ibaraki 305-0006, Japan
}

Yokota et al. 2016), which indicates that stress is being accumulated in preparation for future large inter-plate earthquakes. Recurrence intervals of large $(M>8)$ earthquakes around the Nankai Trough are approximately 100-150 years (e.g., Ando 1975). To investigate the mechanism of large inter-plate earthquakes and construct tsunamigenic earthquake scenarios, simulations including dynamic source ruptures have been extensively 
conducted (e.g., Hori et al. 2004; Hok et al. 2011; Hyodo et al. 2014; Kim et al. 2016).

According to the unified hypocenter catalog of the Japan Meteorological Agency (JMA) and the International Seismological Centre-Global Earthquake Model (ISC-GEM) catalog (Storchak et al. 2013), the seismicity of regular earthquakes in offshore regions of Shikoku, Kii, and Tokai has been quite low, especially on the PHS interface. Oceanfloor observations in the Tonankai region also could not detect earthquakes on the PHS interface (Fig. 7 of Nakano et al. 2015). However, on April 1, 2016, a shallow moderate earthquake suddenly occurred at the southeast offshore Mie prefecture, Kii Peninsula, Japan. The magnitude estimated by the JMA is 6.5 . The epicenter of this earthquake was located near the rupture area of the 1944 Tonankai (M7.9) earthquake (e.g., Kikuchi et al. 2003; yellow star in Fig. 1 is the epicenter from the JMA catalog). Seismic waves radiated from this earthquake were well recorded by nationwide seismic networks of the high-sensitivity seismograph network (Hi-net) and the full-range seismograph network (F-net), which are operated by the National Research Institute for Earth Science and Disaster Resilience, Japan (NIED; Okada et al. 2004). A small tsunami caused by the seafloor deformation during this moderate earthquake was also observed at seafloor sites of the Dense Oceanfloor Network system for Earthquakes and Tsunamis (DONET; Kaneda et al. 2015; Kawaguchi et al. 2015), which is collaboratively operated by NIED and the Japan Agency for Marine-Earth Science and Technology (JAMSTEC). A slow-slip event and episodic tremors near the trench were also detected after this earthquake (Annoura et al. 2017; Araki et al. 2017). Hereafter, we call this earthquake the "SE offshore Mie earthquake."

The focal mechanism and depth of the 2016 SE offshore Mie earthquake may provide us with important information on stress accumulation on the PHS interface around the Tonankai region. By using observed waveforms, routine analyses of first-motion polarization and moment tensor (MT) inversion with a conventional onedimensional (1D) Earth model were conducted. Around

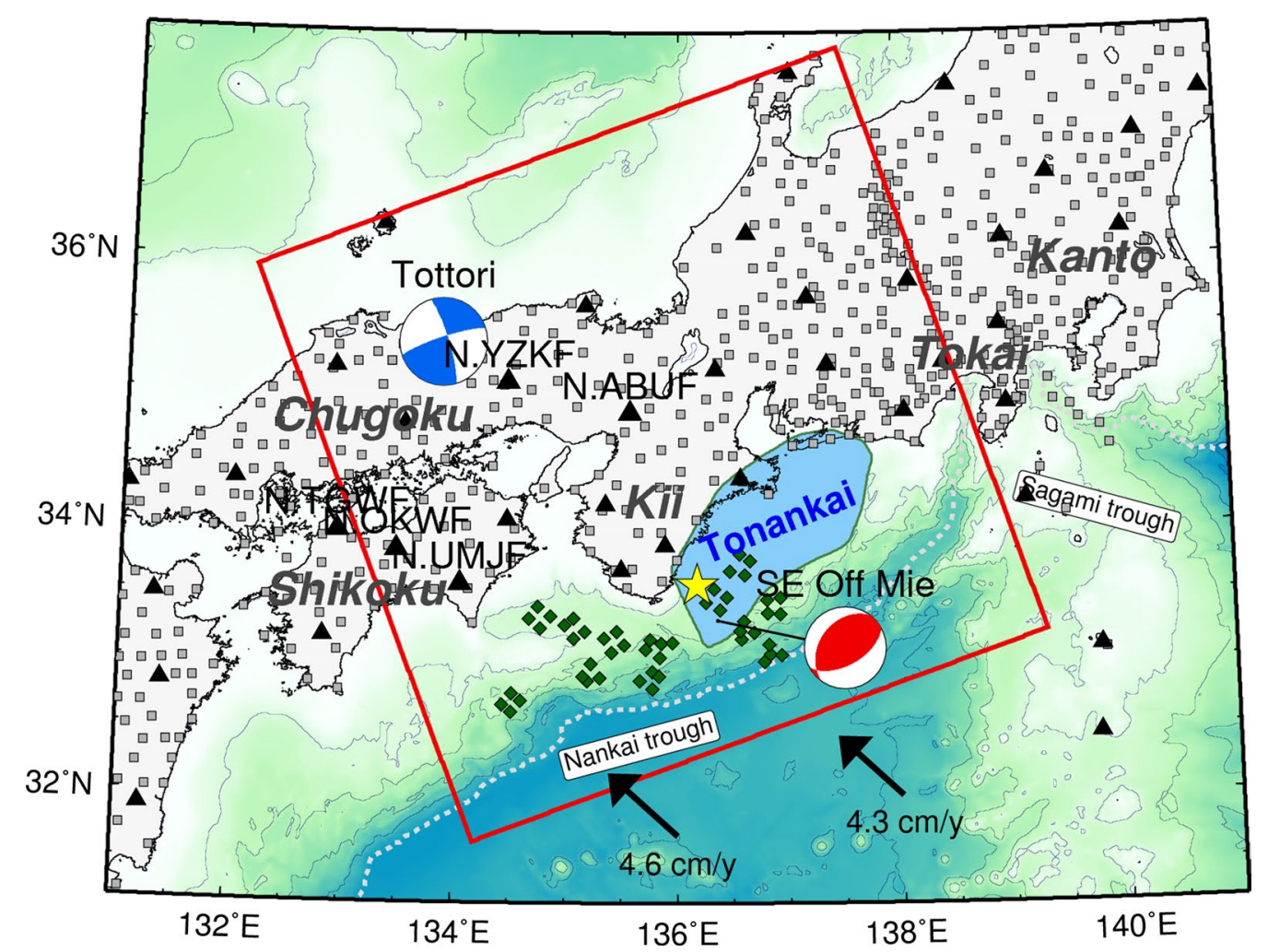

Fig. 1 Map and focal mechanisms of target earthquakes. Gray squares and black triangles are Hi-net and F-net stations, respectively. Green diamonds are station locations of DONET. The yellow star represents the epicenter of the 1944 Tonankai earthquake provided by the JMA catalog. The blue shaded area represents the expected source region of the Tonankai earthquake (Earthquake Research Committee, Long-term evaluation of earthquakes in the Nankai Trough, 2001, available at http://www.jishin.go.jp/main/chousa/01sep_nankai/index.htm). Arrows in the map indicate the convergence rate of the PHS referred from Seno et al. (1993). Focal mechanisms of the 2016 southeast offshore Mie (M6.5) and central Tottori (M6.6) earthquakes are from the F-net MT catalog. The red square represents the horizontal coverage of the model for the 3D FDM simulations 
the epicenter region, however, various three-dimensional (3D) heterogeneities, such as the Philippine Sea plate, bathymetry, accretionary prism (oceanic sediments), and seawater, exist and these may affect the estimation of source parameters. The Hi-net first-motion solution of this earthquake using a $1 \mathrm{D}$ velocity model gave a normal-faulting mechanism at a depth of $18 \mathrm{~km}$, but this is an incorrect solution because of the misestimation of the depth and takeoff angles due to the low-angle dipping slab (Takemura et al. 2016).

The F-net MT solution using regional displacement waveforms of this earthquake (red focal sphere in Fig. 1) shows a reverse faulting mechanism with a dip angle of $38^{\circ}$ and a depth of $14 \mathrm{~km}$, which is higher and shallower than solution from the global centroid moment tensor (GCMT) catalog (Ekström et al. 2012). Both solutions are located below the PHS interface $(\sim 10 \mathrm{~km}$; e.g., Hirose et al. 2008), suggesting that this earthquake was intra-slab earthquake. On the other hand, the hypocenter depth of this earthquake by travel time analysis of oceanfloor records (Wallace et al. 2016) was $11 \mathrm{~km}$, where the PHS interface or the mega-splay fault exists (e.g., Park et al. 2002). The mega-splay fault is branching fault that have the potential to cause large coseismic slip (e.g., Fukao 1979). In evaluations of Green's functions for MT inversion using long-period (20-100 s) full displacement waveforms (e.g., Fukuyama et al. 1998; Kuge 2003; Sokos and Zahradnik 2008; Tsuruoka et al. 2009), 1D velocity structure models have been used rather than 3D models. Some trial studies of MT inversion using landarea 3D and offshore two-dimensional (2D) heterogeneous models have been developed (e.g., Ramos-Martínez and McMechan 2001; Okamoto 2002; Liu et al. 2004; Lee et al. 2010; Hingee et al. 2011; Sugioka et al. 2012; Hejrani et al. 2017). The results of these MT inversions generally demonstrate good waveform fitting compared with traditional 1D MT inversions. Recent studies and observed waveforms of the 2016 SE offshore Mie earthquake (Fig. 2) have demonstrated that heterogeneous structures around the offshore region, such as the accretionary prism and seawater, significantly affect the propagation and excitation of long-period ( $20 \mathrm{~s})$ surface waves (e.g., Shapiro et al. 2002; Furumura et al. 2008; Nakamura et al. 2015; Guo et al. 2016; Noguchi et al. 2016; Todoriki et al. 2017). Furthermore, since the accretionary prism and subducting PHS are three-dimensionally complicated in the Nankai subduction zone (Figs. 1 and 3), to achieve precise MT inversion of offshore earthquakes in the subduction zone, 3D heterogeneities should be fully taken into account in the model.

In this study, to obtain source parameters of the 2016 SE offshore Mie earthquake, we conduct MT inversion of this earthquake using a 3D heterogeneous structure model. Before MT inversion with observed data, by using synthetic long-period seismograms of an assumed low-angle thrust earthquake at a depth near the PHS interface, we investigate the effects of 3D heterogeneous structures on the MT inversion of shallow offshore earthquake. We demonstrate that both the accretionary prism and subducting PHS provide better estimations of centroid depths and focal mechanisms of offshore earthquakes in the subduction zone. We then conduct an MT inversion of the 2016 SE offshore Mie earthquake using Green's functions derived from a full 3D model. We also compare the spatial distribution of first-motion polarizations between observations and simulations using our MT results. According to both the MT inversion and first-motion analyses, we conclude that this earthquake is thrust faulting occurred on the PHS interface, rather than on the mega-splay fault.

\section{Observed F-net broadband records during the 2016 SE offshore Mie earthquake}

We analyzed displacement waveforms of the 2016 SE offshore Mie earthquake recorded at F-net stations, where broadband velocity seismometers are installed at outcrop rock sites. First, we calculated spectra of observed displacement waveforms during this earthquake. Displacement waveforms were obtained by integrating trend-removed F-net velocity seismograms. We also calculated spectra for a typical M6.6 crustal earthquake that occurred on October 21, 2016 in the central Tottori, Chugoku region (blue focal sphere in Fig. 1) as a reference.

Figure 2a shows the displacement spectra of the two moderate earthquakes as a function of the period of seismic waves. Colored lines are spectra of displacement waveforms observed at F-net station N.ABUF (see Fig. 1), which is located approximately $180 \mathrm{~km}$ from both epicenters. Spectra of the crustal earthquake (lower panel) show simple $\omega$-squared type spectra. Spectral amplitudes increase with increasing periods from 0.2 to $5 \mathrm{~s}$ and become almost constant for periods greater than $5 \mathrm{~s}$. On the other hand, displacement spectra for the 2016 SE offshore Mie earthquake (upper panel) show a clear spectral peak around the periods of 10-20 s, which correspond to the dominant period range of ground motions propagating through the accretionary prism in the Nankai subduction zone (e.g., Hayakawa et al. 2005; Furumura et al. 2008; Nakamura et al. 2015).

Such differences between crustal and offshore earthquakes were also found in displacement waveforms at N.ABUF. Figure $2 b-d$ shows observed displacement waveforms recorded at N.ABUF for three period ranges of 5-20, 20-100, and 30-100 s. Typical MT inversion of moderate earthquakes is conducted in the period range of 20-100 s. Strong long-period ground motions in large 

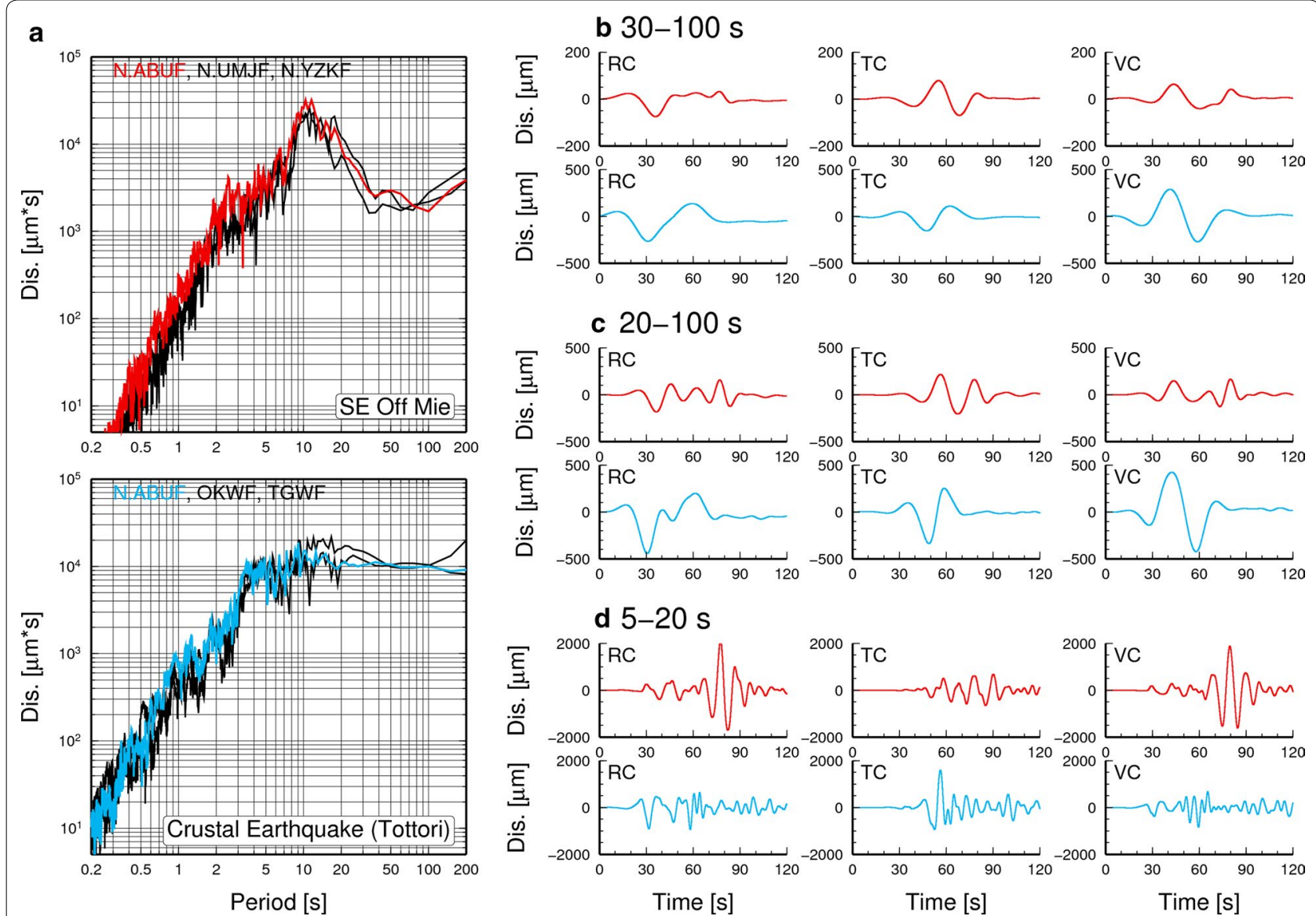

c $20-100 \mathrm{~s}$
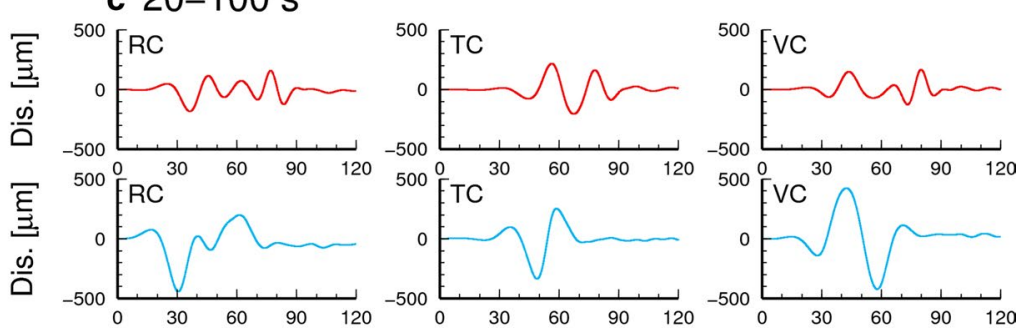

\section{d 5-20 s}
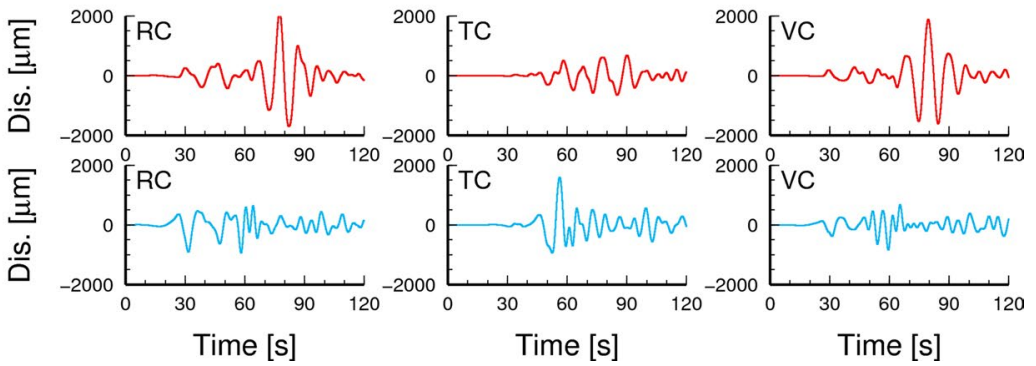

Fig. 2 Broadband F-net displacement records during the 2016 southeast offshore Mie earthquake. a Displacement spectra of the SE offshore Mie earthquake (M6.5) and central Tottori earthquake (M6.6), which occurred within the crust. Locations of stations and the epicenter are shown in Fig. 1. Displacement waveforms at F-net station N.ABUF for periods of b 30-100 s, c 20-100 s, and $\mathbf{d} 5-20$ s. Red and blue lines are observed records at N.ABUF during the SE offshore Mie and central Tottori earthquakes, respectively. RC, TC, and VC in (b)-(d) represent the radial, transverse, and vertical components, respectively

sedimentary basins are frequently observed in the period range of 5-20 s (e.g., Miyake and Koketsu 2005; Yoshimoto and Takemura 2014; Nakamura et al. 2015). In displacement waveforms of the central Tottori earthquake (blue lines), simple pulse-like waveforms can be recognized, and these can be modeled by a simple $1 \mathrm{D}$ velocity model. On the other hand, displacement waveforms of the 2016 SE offshore Mie earthquake illustrated delays and elongation of surface waves in the radial and vertical components. Furthermore, even for the reverse faulting mechanism, large amplitudes of the transverse component were observed. Such characteristics still appeared in seismograms for the longest period (30-100 s) band. These differences may be caused by differences in heterogeneous structures along the propagation paths. Simple $1 \mathrm{D}$ analysis revealed that almost energy of surface waves for periods less than $30 \mathrm{~s}$ was trapped within the sedimentary layer (layer with $V_{\mathrm{S}}=1.0 \mathrm{~km} / \mathrm{s}$ in Additional file 1: Figure S1), indicating that Love waves are strongly influenced by detailed structures within the accretionary prism. According to this simple 1D analysis, we selected a period range of $30-100 \mathrm{~s}$ for the MT inversion of offshore moderate earthquakes, which is longer than corner period of the 2016 SE offshore earthquake (Fig. 2a).

\section{Method and models}

Finite-difference method simulation and moment tensor inversion

Green's functions were calculated via 3D finite-difference method (FDM) simulations. The 3D model of the FDM simulations covered a volume of $512 \times 512 \times 128 \mathrm{~km}^{3}$ (enclosed by the red square in Fig. 1), which was discretized with grid intervals of $0.2 \mathrm{~km}$ and $0.1 \mathrm{~km}$ in the horizontal and vertical directions, respectively, and a time step of $0.005 \mathrm{~s}$. Technical details of the simulations are described in Takemura et al. (2015a, 2016). 3D FDM 

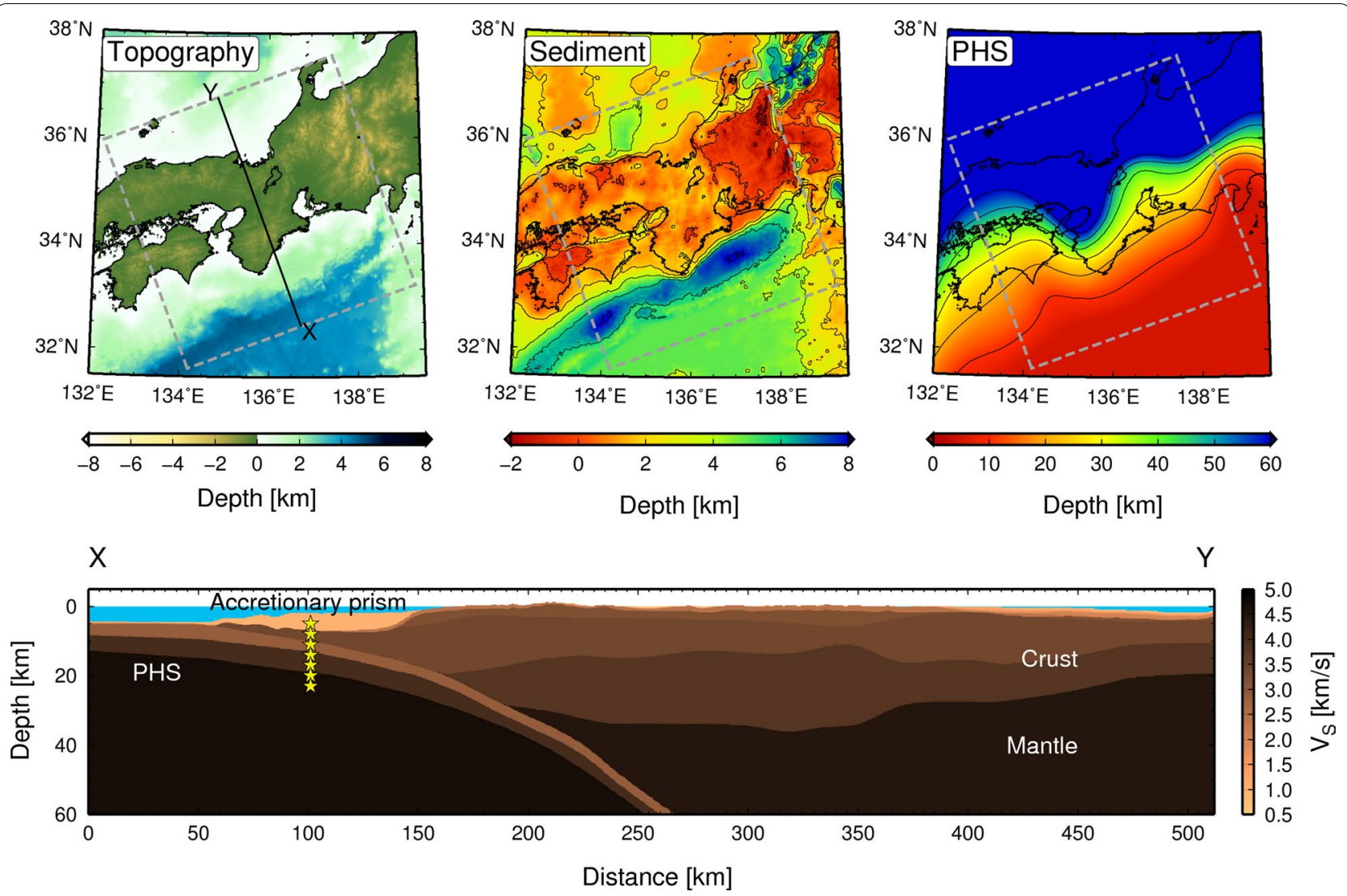

Fig. 3 Assumed seismic velocity structure model in the 3D simulations. Upper panels show depth variations of the topography, bedrock, and upper surface of the Philippine Sea slab (PHS). The dashed gray rectangle represents the horizontal coverage of the model for $3 \mathrm{D}$ simulations. Assumed S-wave velocity structure along the $X-Y$ profile is shown in the bottom subfigure. Blue and white areas represent seawater $\left(V_{P}=1.5 \mathrm{~km} / \mathrm{s}\right.$, $V_{\mathrm{S}}=0.0 \mathrm{~km} / \mathrm{s}$, and $\left.\rho=1.0 \mathrm{~g} / \mathrm{cm}^{3}\right)$ and $\operatorname{air}\left(V_{\mathrm{p}}=V_{\mathrm{S}}=0.0 \mathrm{~km} / \mathrm{s}\right.$ and $\left.\rho=0.001 \mathrm{~g} / \mathrm{cm}^{3}\right)$ columns, respectively

simulations were efficiently conducted via parallel FDM code (after Furumura and Chen 2004) by using 256 nodes (1024 cores) of the Earth Simulator at JAMSTEC. Each simulation required $1.3 \mathrm{~TB}$ of computer memory and a wall-elapse time of $1.5 \mathrm{~h}$ to evaluate seismic wave propagation for $300 \mathrm{~s}$ by 60,000 time step calculations.

Similar to the NIED F-net routine MT inversion (Fukuyama et al. 1998; Kubo et al. 2002), the epicenter location was fixed to one from the JMA unified catalog. This assumed epicenter location is very close to that from a travel time analysis using an oceanfloor network (Wallace et al. 2016). Five element moment tensors (see $M_{1} \sim M_{5}$ in Fig. 1 of Kikuchi and Kanamori 1991), except for the isotropic one, were assumed at depths of $5,8,11,14,17$, 20, and $23 \mathrm{~km}$ (yellow stars in Fig. 3). Moment tensor $\mathbf{M}$ can be represented by a linear combination of element moment tensors $\mathbf{M}_{i}$ and weight $a_{i}$ :

$$
\mathbf{M}=\sum_{i=1}^{5} a_{i} \mathbf{M}_{i}
$$

The source time function was represented by a cosineshape function (Ji et al. 2003) with a duration of $1 \mathrm{~s}$. By using calculated Green's functions of element moment tensors $(\mathbf{G})$ and observed data $\mathbf{d}$, the least square solutions for weights of each element moment tensor $\left(a_{i}\right)$ were obtained by using the following equation:

$$
\mathbf{A}=\left(\mathbf{G}^{\mathrm{T}} \mathbf{G}\right)^{-1} \mathbf{G}^{\mathrm{T}} \mathbf{d}
$$

The fit between observed and synthetic displacements was evaluated by the variance reduction. Variance reductions were evaluated for the MT solution of each centroid depth. The solution with the maximum variance reduction is the optimal solution. The variance reduction (V.R.) can be calculated by the following equation:

V.R. $=\left(1-\frac{\sum_{i} \int\left[u_{i}^{\text {Obs. }}(t)-u_{i}^{\text {Syn. }}(t)\right]^{2} \mathrm{~d} t}{\sum_{i} \int\left[u_{i}^{\text {Obs. }}(t)\right]^{2} \mathrm{~d} t}\right) \times 100[\%]$ 
where $u_{i}^{\text {Obs. }}(t)$ and $u_{i}^{\text {Syn. }}(t)$ are the observed and synthetic displacement waveforms for periods of 30-100 s at $i$ th F-net stations, respectively. Note that if synthetic waveforms completely match the observed ones and noise signals are not considered, the V.R. becomes $100 \%$.

\section{Velocity structure models and Green's functions}

The $3 \mathrm{D}$ velocity structure model was constructed based on the Japan Integrated Velocity Structure Model (JIVSM; Koketsu et al. 2012), which has been widely used in many seismological analyses around Japan (e.g., Koketsu et al. 2011; Maeda et al. 2014; Guo et al. 2016; Takemura et al. 2015b, c, 2017; Miyazawa 2016; Petukhin et al. 2016; Todoriki et al. 2017), and a long-period ground motion hazard map of Japan (http://www.jishin.go.jp/evaluation/seismic_hazard_map/lpshm/12_choshuki/). The PHS upper surface of the JIVSM is consistent with other models (e.g., Hirose et al. 2008; Tsuji et al. 2014). The assumed $S$-wave velocity structure along profile $X-Y$ is illustrated in Fig. 3. The JIVSM includes sedimentary layers (land-area sedimentary basin, oceanic sediments), the crustal structure, and two subducting oceanic plates. The seawater layer was modeled as an elastic medium with $V_{\mathrm{P}}$ of $1.5 \mathrm{~km} / \mathrm{s}, V_{\mathrm{S}}$ of $0.0 \mathrm{~km} / \mathrm{s}$, and density $\rho$ of $1.04 \mathrm{~g} /$ $\mathrm{cm}^{3}$. The air column was modeled as a vacuum with $V_{\mathrm{P}}$ of $0.0 \mathrm{~km} / \mathrm{s}, V_{\mathrm{S}}$ of $0.0 \mathrm{~km} / \mathrm{s}$, and $\rho$ of $0.001 \mathrm{~g} / \mathrm{cm}^{3}$, where no seismic wave propagates and the zero stress condition is implicitly satisfied. Depths of the JIVSM basement, plate interface, and oceanic Moho beneath the epicenter were approximately 7, 10, and $19 \mathrm{~km}$, respectively. Due to the minimum $S$-wave velocity $(1 \mathrm{~km} / \mathrm{s})$ and grid interval $(0.02 \mathrm{~km})$, our FDM simulations using the JIVSM can evaluate propagation of seismic waves for periods longer than $1.4 \mathrm{~s}$. The minimum period of FDM simulations is much shorter than the period range of the MT inversion, but we also discuss broadband seismic wave propagation of the 2016 SE offshore Mie earthquake, such as first- $P$ arrivals and strong long-period ground motions.

In order to investigate the effects of the seawater, accretionary prism, and subducting PHS on the MT inversion, we prepared two other sets of Green's functions derived from two simpler models. One model was the F-net $1 \mathrm{D}$ velocity structure model (Kubo et al. 2002), which has been used in F-net routine analyses. Green's functions of the F-net 1D model were evaluated via a computer program for wave number integration provided by Herrmann (2013), which can be conducted on desktop personal computers. The other model was the JIVSM without the accretionary prism and seawater layers. In the accretionary prism and seawater layers of this model, physical parameters were replaced with ones of the upper crust and air columns, respectively. Since calculation costs of FDM simulations are controlled by the grid interval and minimum $S$-wave velocity, if we obtained accurate source parameters by using this model, the calculation costs for evaluating the 3D Green's functions were significantly reduced compared to those for the model with low-velocity $(<2 \mathrm{~km} / \mathrm{s})$ layers. Hereafter, we call this model the "simplified JIVSM (sJIVSM)."

Figure 4 shows examples of three-component Green's functions for pure strike-slip $\left(M_{x y}=1.0\right)$ and dip slip $\left(M_{z z}=-M_{x x}=1.0\right)$ sources. The components $x, y$, and $z$ correspond to the north, east, and down directions, respectively (Aki and Richards 2002). Green's functions of the JIVSM (red lines) exhibited large-amplitude and long-duration displacements due to the accretionary prism, especially in the transverse component, although no long-duration coda appeared in the ones of the other two models. Differences of Green's functions among the models decreased with increases in the centroid depth.

To quantify the differences of Green's functions among the models, we calculated the variance reductions of 11-km depth Green's functions for three model pairs, namely F-net 1D model/sJIVSM (Fig. 5a), F-net 1D model/JIVSM (Fig. 5b), and sJIVSM/JIVSM (Fig. 5c). In these experiments, $u_{i}^{\text {Obs. }}(t)$ and $u_{i}^{\text {Syn. }}(t)$ in Eq. (3) are Green's functions for periods of 30-100 s at F-net stations derived from each model pair. Variance reductions of pure dip slip Green's functions for each model pair were evaluated at assumed $\mathrm{Hi}$-net/F-net stations in the model because F-net stations are too sparse to evaluate this. Spatial distributions of variance reductions (Fig. 5) showed laterally asymmetric patterns, which reflect complex effects of $3 \mathrm{D}$ heterogeneous structures in the model (upper panels of Fig. 3).

Variance reductions between the F-net 1D model and 3D model (sJIVSM and JIVSM; Fig. 5a, b) were small except for in the areas of Kii Peninsula and eastern Shikoku. Particularly, in Fig. 5a, effects of the 3D subducting PHS clearly appeared. Smaller variance reductions were found at both land and coastal areas of the eastern Shikoku and western Tokai regions, where the configuration of the PHS is very complex (upper-right of Fig. 3). These results suggest that numerical simulations using the F-net $1 \mathrm{D}$ velocity structure cannot reproduce the seismic wave propagation of offshore earthquakes even for longer periods (30-100 s), especially in the transverse component, i.e., Love waves.

To visualize the effects of low-velocity layers (accretionary prism and seawater), we also calculated variance reductions between SJIVSM and JIVSM (Fig. 5c). Variance reductions of the radial and vertical components for the sJIVSM/JIVSM pair showed relatively higher values compared to ones for the 1D/3D model pair (Figs. 5a, b). Smaller variance reductions appeared around the Shikoku and Tokai regions. Seismic waves observed 

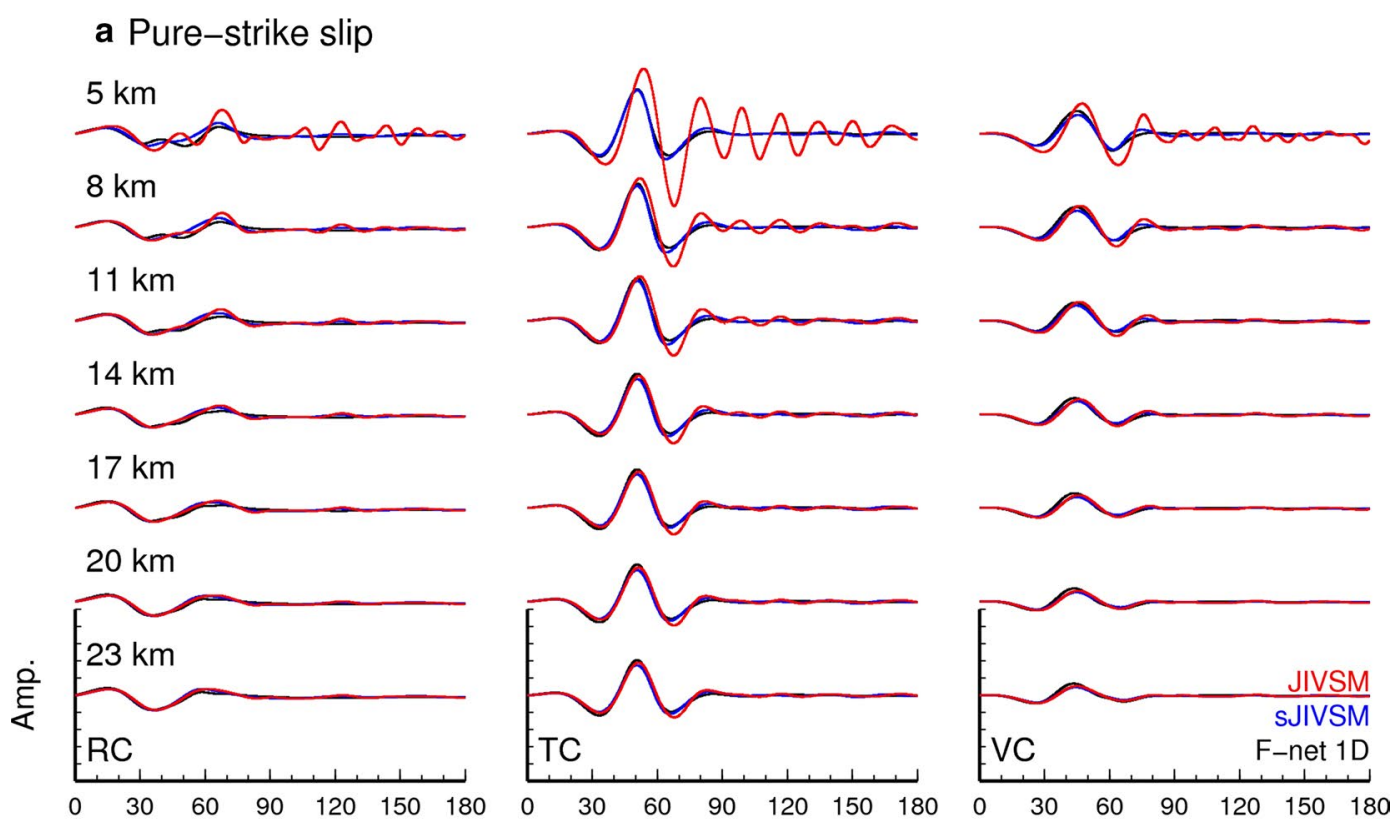

b Pure-dip slip
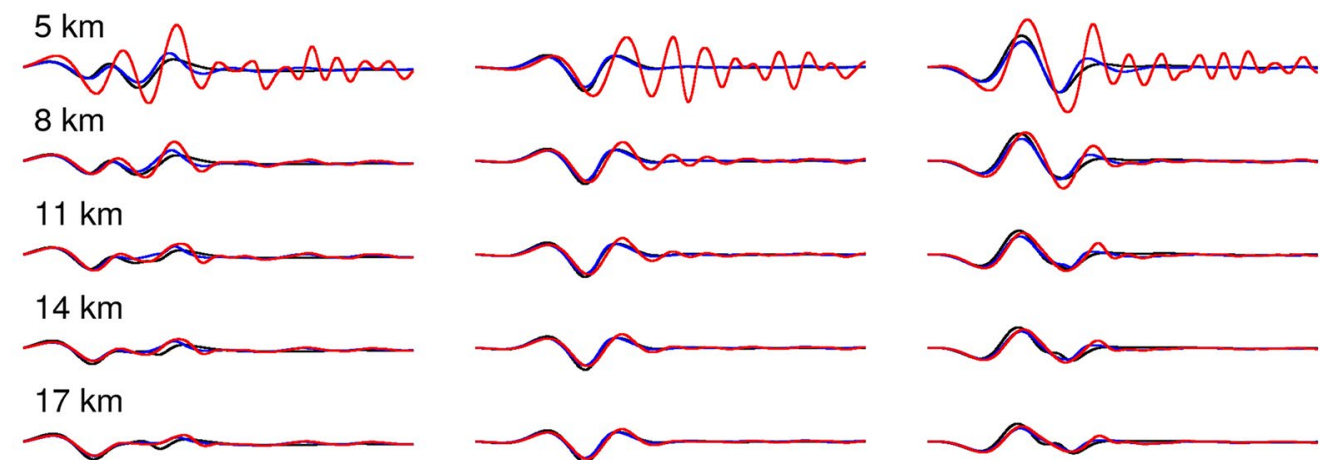

$17 \mathrm{~km}$
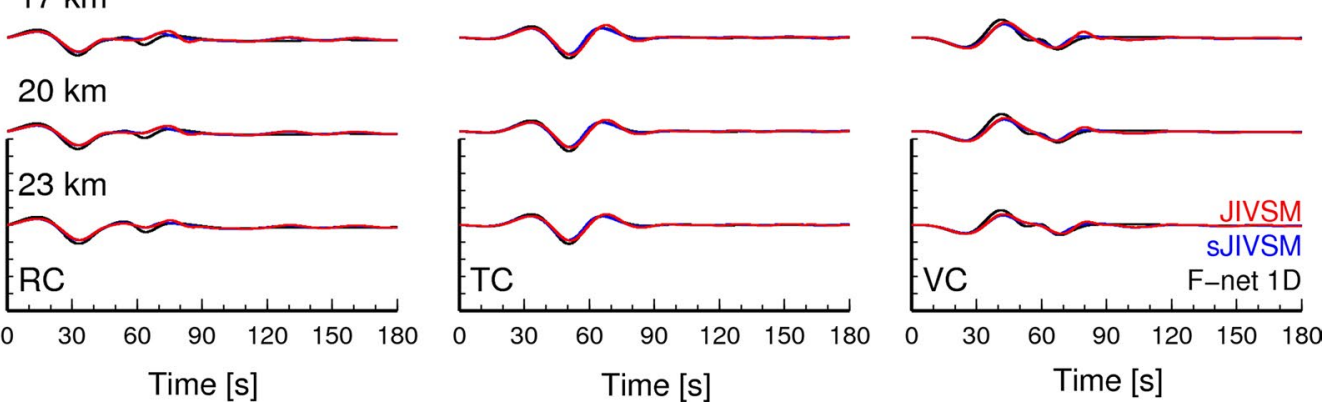

Fig. 4 Depth variation of Green's functions for pure strike- and pure dip slip moment tensors. Three-component displacement waveforms for the a pure strike-slip $\left(M_{x y}=1.0\right)$ and $\mathbf{b}$ pure dip slip $\left(M_{z z}=-M_{x x}=1.0\right)$ sources. A band-pass filter with passed periods of 30-100 s was applied into each trace recorded at F-net station N.ABUF. Red, blue, and black traces are Green's functions derived from the JIVSM (Koketsu et al. 2012), SJIVSM (JIVSM without an accretionary prism and seawater), and F-net 1D velocity structure model (Kubo et al. 2002), respectively

at regions with smaller variance reductions efficiently propagated through the accretionary prism. Especially in the transverse component, variance reduction was significantly smaller than other two components. Generally, high sensitivities of Love waves appeared at shallow depths compared to Rayleigh waves (e.g., Nishida et al. 2008). The shallower low-velocity structure within the accretionary prism affects the excitation and propagation features of Love waves toward these regions. 

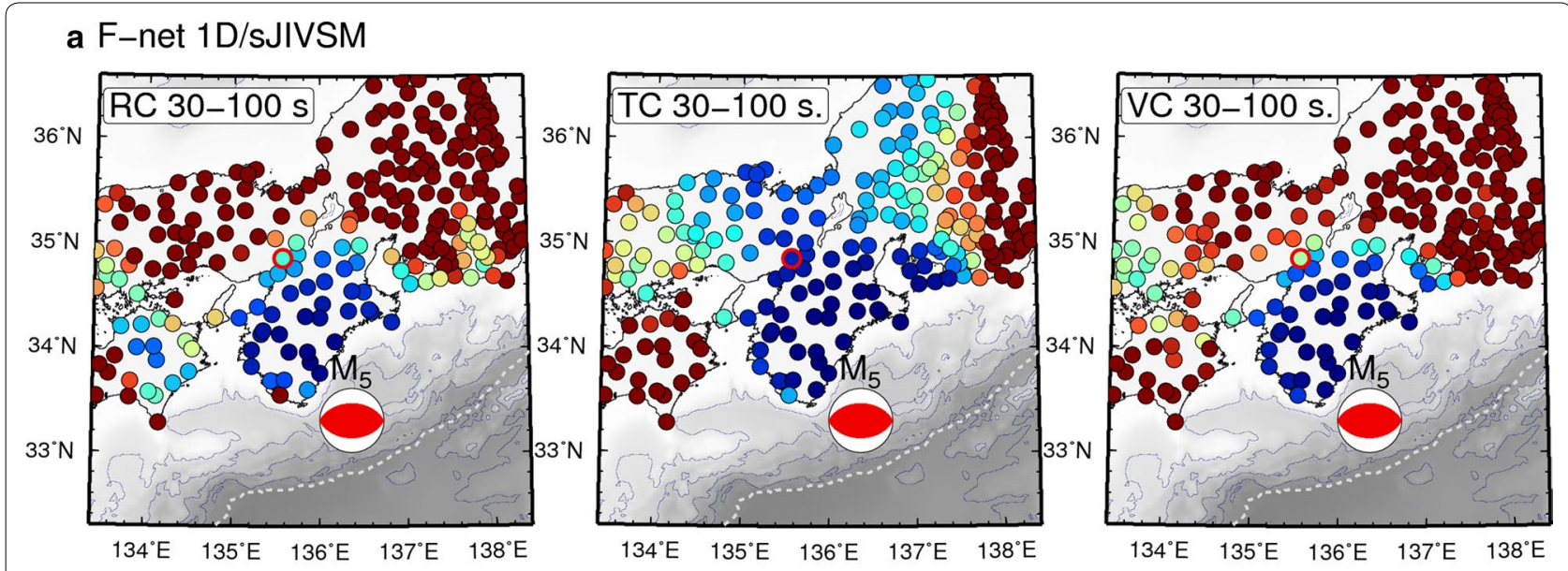

b F-net 1D/JIVSM
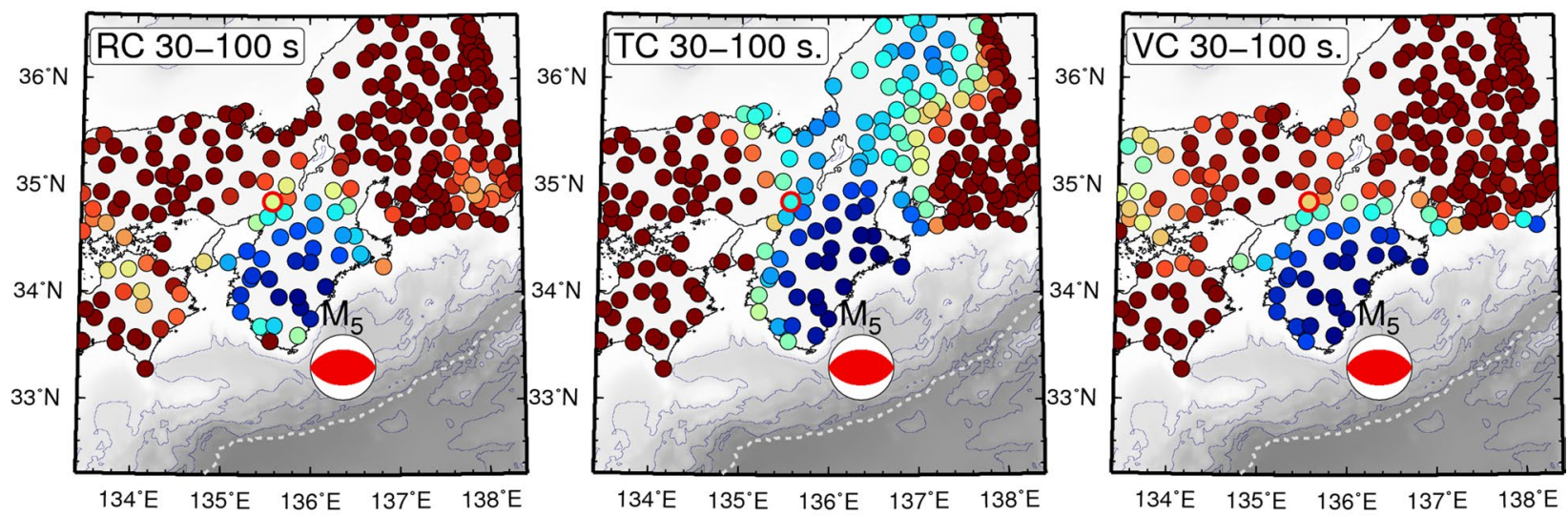

c SJIVSM/JIVSM
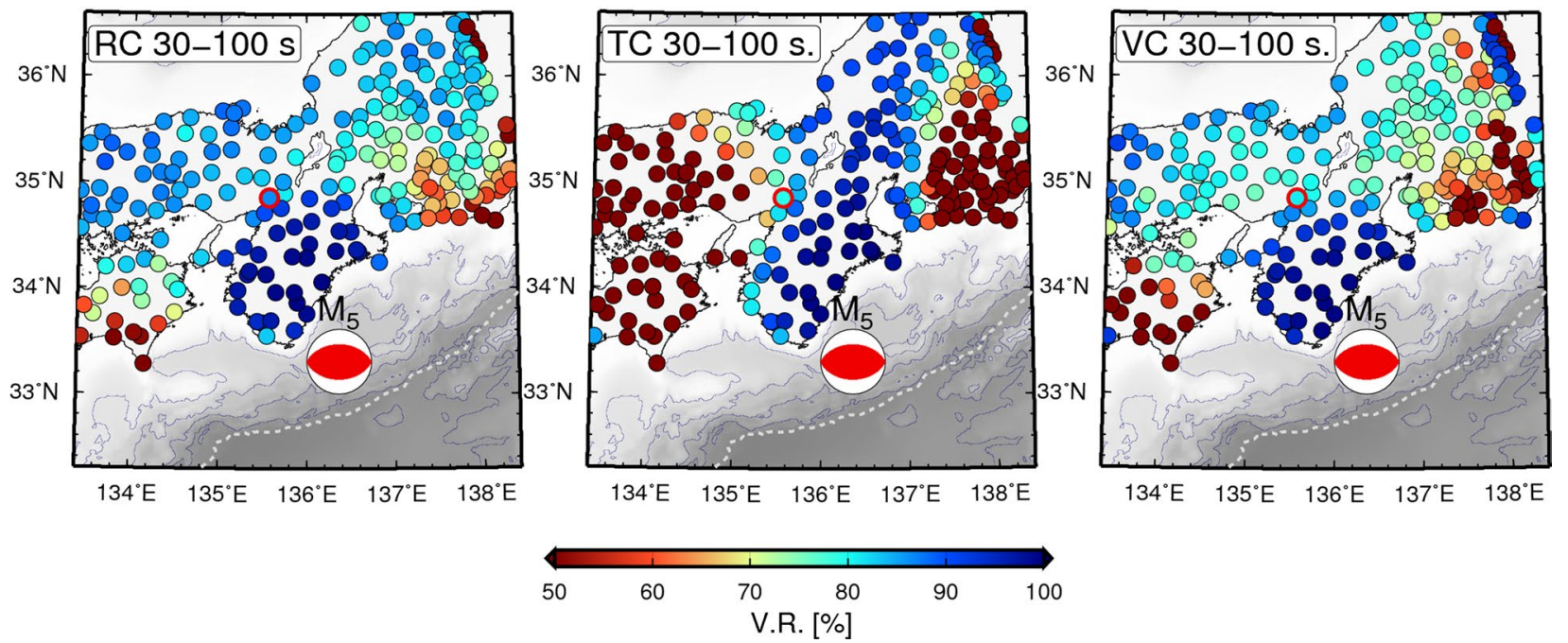

Fig. 5 Spatial distribution of waveform differences among Green's functions for three model pairs. Waveform differences were evaluated by the variance reduction (V.R.) of Eq. (3). The assumed moment tensor is the pure dip slip $\left(M_{z z}=-M_{x x}=1.0\right)$ source at a depth of $11 \mathrm{~km}$. A band-pass filter with periods of 30-100 s was applied to each trace. Red enclosed symbols indicate F-net N.ABUF 


\section{Effects of 3D heterogeneous structures on MT inversion}

Differences of Green's functions are illustrated in "Method and models" section. Next, we investigated the effects of these differences on the MT inversion. By using the JIVSM, we made synthetic waveforms of a test earthquake, which was characterized by a pure doublecouple point source of thrust faulting at a depth of $11 \mathrm{~km}$ (near the PHS interface) with strike angle of $\phi_{S}=215^{\circ}$, dip angle of $\delta=10^{\circ}$, rake angle of $\lambda=66^{\circ}$, and moment magnitude of $M w=5.7 \quad\left(M o=4.9 \times 10^{17} \mathrm{Nm}\right)$. Target waveforms, which were calculated by FDM simulations of the test earthquake in the JIVSM, are illustrated by black lines in Figs. 6 and 7. We conducted an MT inversion of this test earthquake by using Green's functions derived from the two simpler models (F-net 1D model and sJIVSM) to demonstrate the effects of 3D heterogeneous structures on the MT analysis. In these analyses, the traditional time shifting technique was not applied (e.g., Zhu and Helmberger 1996). Noise signals were not assumed in the following synthetic tests. In the case of these MT inversions, $u_{i}^{\text {Obs. }}(t)$ in Eq. (3) is the synthetic seismogram of the test earthquake in the JIVSM.

Figure 6 shows the results of the MT inversion for the test earthquake using Green's functions of the F-net 1D model. Similar values of variance reductions are shown in the right subfigure of Fig. 6. Estimated focal mechanisms, except for shallower ( 5 and $8 \mathrm{~km}$ ) ones, were characterized by reverse faulting with a relatively higher dip angle compared to the correct one (black focal sphere in the right-bottom corner). The F-net MT solution for the 2016 SE offshore Mie earthquake was also characterized by a high-angle reverse faulting mechanism (red focal sphere in Fig. 1). According to our test and the F-net solution for the 2016 SE offshore Mie earthquake, in the case of the MT inversion for subduction zone earthquakes that occurred outside of seismic arrays, centroid depths and dip angles were not well constrained by using the $1 \mathrm{D}$ velocity model. Similar results were reported in a study of MT inversion around the Australian region by Hingee et al. (2011). Synthetic displacements of best-fit MT results (red traces) could not explain the large amplitude of the transverse component and later phases of target waveforms (black traces).

Next, we conducted an MT inversion of the test earthquake using Green's functions of sJIVSM (Fig. 7). By introducing the 3D topography/bathymetry, crust, and PHS models, variance reduction using SJIVSM was improved compared to that using the F-net 1D model. The optimal MT result is characterized by low-angle thrust faulting at a depth of $14 \mathrm{~km}$, which was similar mechanism but slightly deeper than the correct solution. However, synthetic displacements of the best MT result (red traces) still could not explain the large amplitude of the transverse component and later phases of target waveforms (black traces). Furthermore, although variance reduction decreased at depths below oceanic Moho of the PHS $(19 \mathrm{~km})$, similar values of variance reductions appeared at depths above the oceanic Moho. This indicates that the centroid depth was not well constrained by using the models without low-velocity layers.

According to the above two experiments, we clarified the effects of the accretionary prism, seawater, and subducting PHS on the MT inversion. The 3D subducting PHS restricts the centroid depths to depths ranging above the oceanic Moho of the PHS, where a steep velocity contrast exists. Large amplitudes of the transverse component and later phases of Rayleigh waves are generated by the accretionary prism and seawater just above the hypocenter. Recent studies from observations and simulations reported that oceanic Airy waves with a group velocity of $1-1.5 \mathrm{~km} / \mathrm{s}$ converted to crustal Rayleigh waves with a group velocity of $3.5 \mathrm{~km} / \mathrm{s}$ (e.g., Sugioka et al. 2012; Nakamura et al. 2015; Noguchi et al. 2016; Todoriki et al. 2017). Slower propagations of surface waves around the oceanic area may become secondary later phases found in the radial and vertical components (Fig. 2b). Since simpler models without lowvelocity layers could not explain the large amplitudes in the transverse component, the accretionary prism made a significant contribution to the excitation of Love waves around the epicenter region. Thus, we conclude that to obtain the precise depth and focal mechanism of offshore earthquakes via MT inversion, a full 3D structure model including the seawater, accretionary prism, and subducting PHS should be required.

\section{MT inversion of the 2016 SE offshore Mie earthquake}

We conducted an MT inversion of the 2016 SE offshore Mie earthquake using Green's functions of 3D models. Figure 8 shows the results of the MT inversion for the 2016 offshore Mie earthquake. The MT results derived by using the sJIVSM and JIVSM are represented by red and gray focal spheres, respectively. At depths greater than $5 \mathrm{~km}$, variance reductions of the JIVSM were higher than the ones of the sJIVSM. The clear peak of the variance reductions of JIVSM appeared at a depth of $11 \mathrm{~km}$, although variance reductions of sJIVSM were similar above the oceanic Moho. The slightly deeper centroid depth of sJIVSM was similar to the MT inversion of synthetic waveforms (Fig. 7). Waveform fittings of the MT results using sJIVSM were not so good, especially in large amplitudes of the transverse component and later phases of radial and vertical components (Additional file 1: Figure S2). According to previous experiments and these 


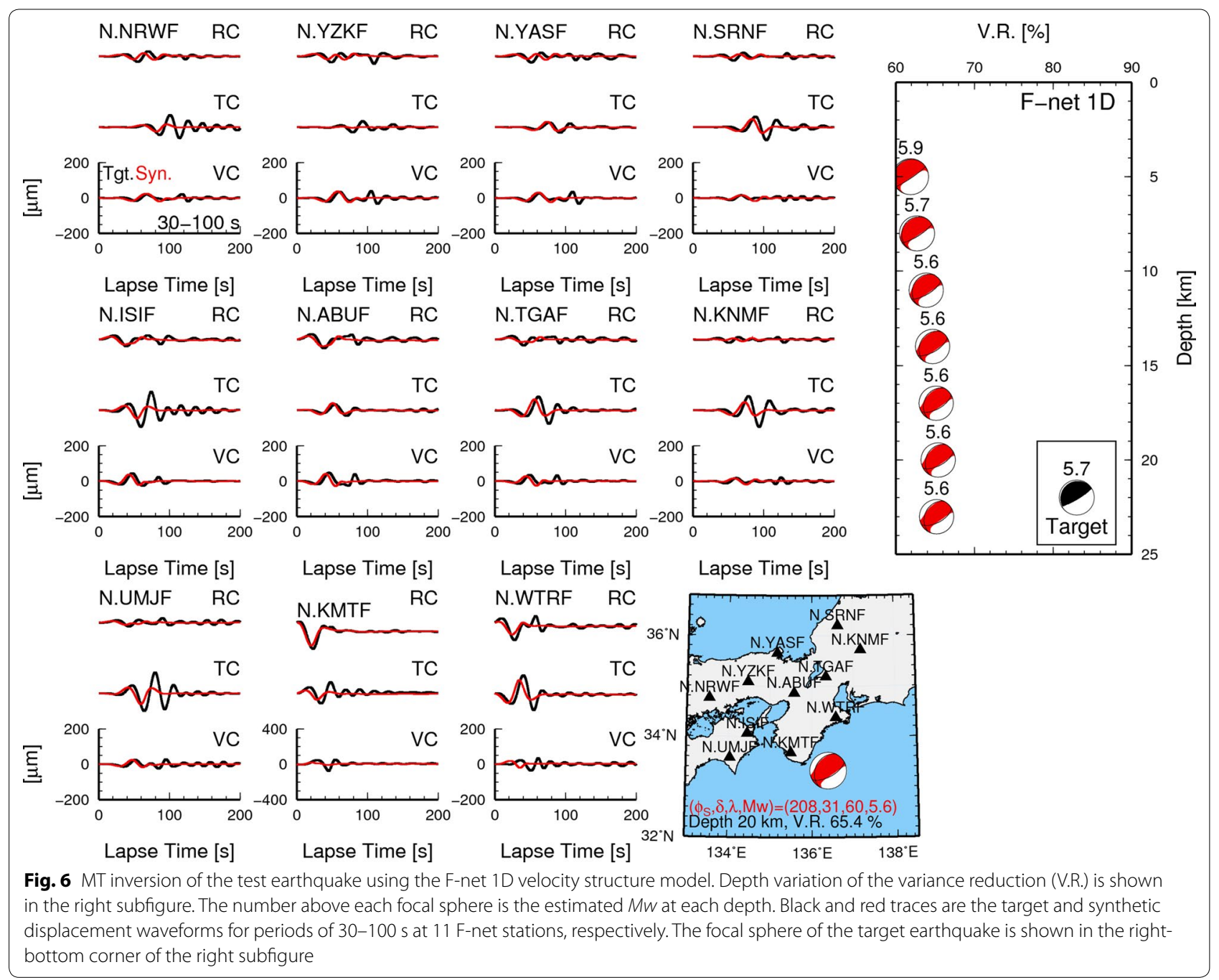

features, we conclude that by introducing 3D structures of the subducting PHS and low-velocity layers, the peak structure of variance reductions can be clearly found at depths ranging between the oceanic Moho $(19 \mathrm{~km})$ and basement of the accretionary prism $(7 \mathrm{~km})$. The centroid depth was constrained to $11 \mathrm{~km}$, where the maximum variance reduction appeared and the PHS interface exists. Conventional 1D analysis by F-net and GCMT show solutions with different dip angle and centroid depth, respectively. Especially, the solution from the GCMT catalog is similar mechanism but located at a depth of $18.8 \mathrm{~km}$ near the oceanic Moho of the PHS, suggesting intra-slab earthquake. A recent study also demonstrated that $1 \mathrm{D}$ analysis of offshore earthquakes could not provide accurate constraints of the centroid depth even if azimuth coverage of the stations was good (Kubota et al. 2017b). To determine the focal mechanism and depth of earthquakes occurred in complex subduction zones, a local
3D heterogeneous structure model should be required. Waveform fittings of the solution with maximum variance reduction (depth of $11 \mathrm{~km}$ ) are also improved by introducing low-velocity layers, especially the accretionary prism, which contributes to the excitation of largeamplitude Love waves in the transverse component. We also conducted the MT inversion by using Green's functions of $11-\mathrm{km}$ source grids with $\pm 0.1^{\circ}$ from the assumed epicenter (Additional file 1: Figure S3). Since similar focal spheres and variance reductions appeared at the north and northeast source grids, the detailed centroid location of this earthquake could be located at the region enclosed by source grids with high variance reductions.

Our MT solution of the 2016 SE offshore Mie earthquake is estimated at a depth of $11 \mathrm{~km}$ and focal mechanism is characterized by a faulting with (strike, dip, rake $)=\left(250^{\circ}, 20^{\circ}, 110^{\circ}\right)$ or $\left(49^{\circ}, 71^{\circ}, 83^{\circ}\right)$ and a moment magnitude of $M w 5.6\left(M o=3.55 \times 10^{17} \mathrm{Nm}\right)$. A low-angle 


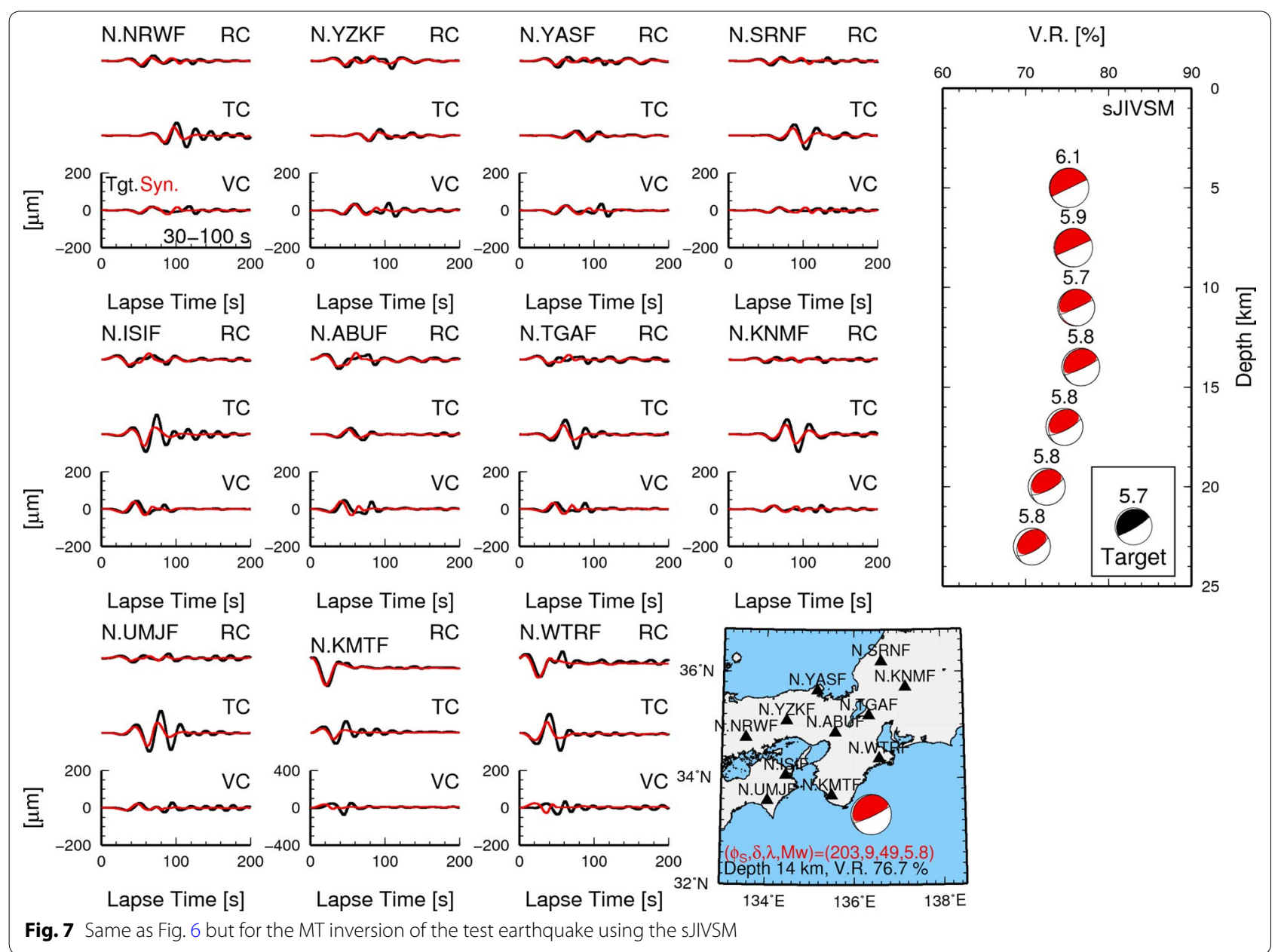

$\left(\delta=20^{\circ}\right)$ thrust faulting mechanism was obtained at the depth near the PHS interface. This suggests that the 2016 SE offshore Mie earthquake can be interpreted as a faulting on the PHS interface. Synthetic displacements of the MT solution successfully explained not only the large amplitudes of the transverse component, but also the later phases in the radial and vertical components. The good fitness of synthetic displacements indicates that the long-period surface waves of offshore earthquakes are excited by the accretionary prism just above the hypocenter. In the MT inversion of offshore earthquakes, the accretionary prism plays important roles, providing depth constraints and long-period surface wave excitation. Large-amplitude Love waves in the transverse component are strongly excited by the accretionary prism. While the estimated moment magnitude ( $M w 5.6)$ was smaller than JMA-scale magnitude (M6.5), this discrepancy can be explained by developments of crustal guided waves and surface waves during shallow earthquakes (e.g., Furumura and Kennett 2001).
To check the estimation error of the focal mechanism of our MT results, we evaluated the variance reductions of F-net displacement waveforms between observations and simulations of a double-couple point source with a fixed seismic moment and centroid depth but changing strike, dip, and rake angles (Fig. 9). Clear trade-offs between the strike and rake angles appeared, as shown in the upper panel of Fig. 9. Large values of variance reduction (V.R. $>76 \%$ ) only appeared in the region with dip angles of $17^{\circ}-32^{\circ}$ and $60^{\circ}-75^{\circ}$ (the lower panel of Fig. 9). The latter one corresponds to the local maximum related with the other nodal plane of the best solution $\left(49^{\circ}, 71^{\circ}\right.$, $83^{\circ}$ ). Thus, the 2016 SE offshore Mie earthquake was characterized by a low-angle thrust faulting mechanism.

\section{Discussion}

Interpretation of the 2016 SE offshore Mie earthquake The MT solution of the 2016 SE offshore Mie earthquake was estimated at a depth of $11 \mathrm{~km}$, which is very close to the PHS interface, and the event was characterized by a low-angle $\left(\delta=20^{\circ}\right)$ thrust earthquake with $M w$ 5.6. Tsuji 


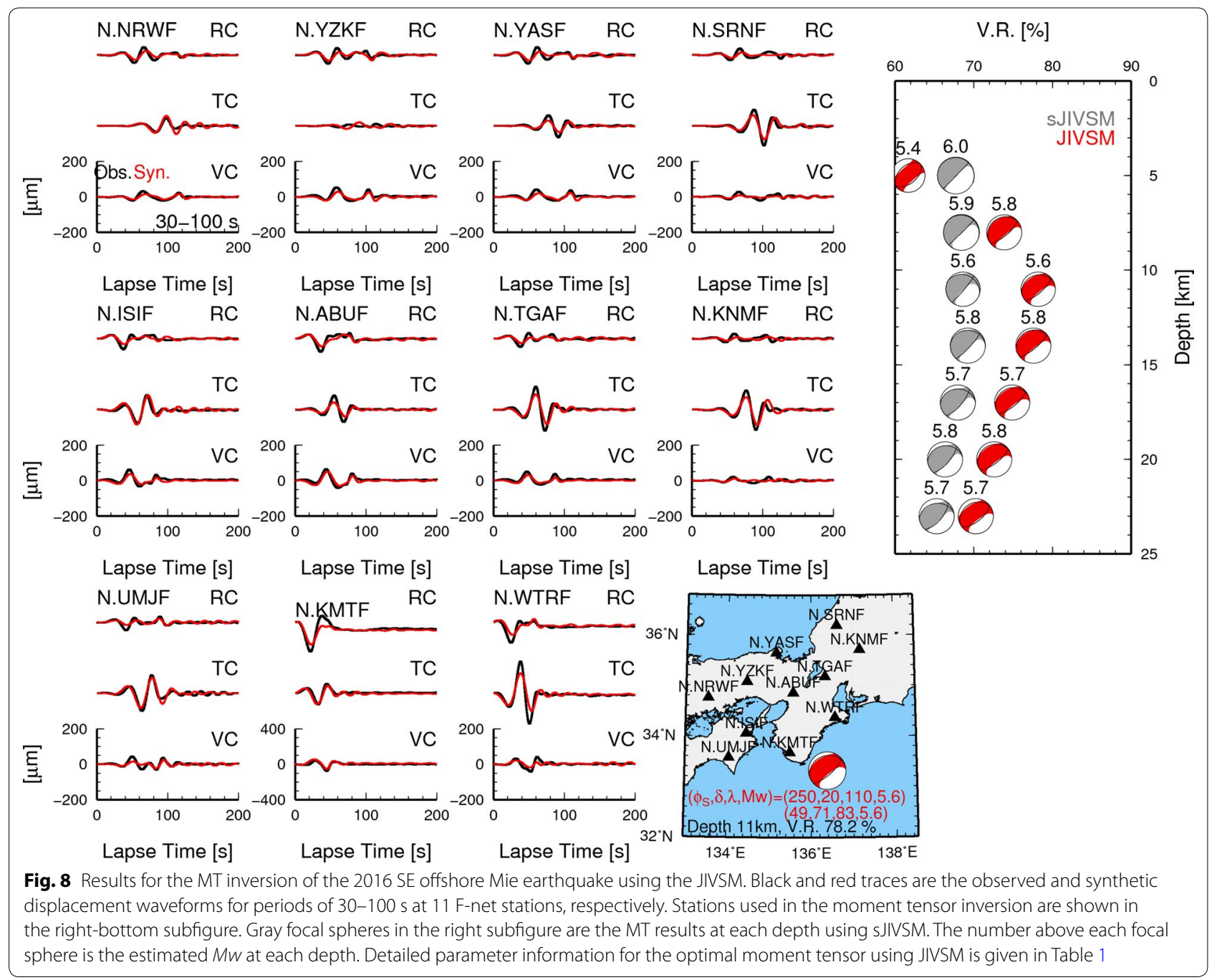

Table 1 Detailed parameter information for the optimal moment tensor of the 2016 SE offshore Mie earthquake. The moment tensor is described in the GCMT format

\begin{tabular}{|c|c|c|c|c|c|c|c|c|c|}
\hline Lon. $\left({ }^{\circ}\right)$ & Lat. $\left(^{\circ}\right)$ & Depth (km) & $M_{r r}$ & $M_{\theta \theta}$ & $M_{\phi \phi}$ & $M_{r \theta}$ & $M_{r \phi}$ & $M_{\theta \phi}$ & Exp. \\
\hline 136.38 & 33.32 & 11 & 1.5086 & 1.4495 & -0.0591 & 2.0573 & 1.7286 & 1.7812 & 24 \\
\hline
\end{tabular}

et al. (2014) investigated detailed structures of the fault systems of the Nankai subduction zone from waveform tomography and reflection surveys along a temporal linear ocean bottom seismometer array, which crosses near the epicenter region of the 2016 SE offshore Mie earthquake. According to their results and our MT solution, the 2016 SE offshore Mie earthquake can be interpreted as a faulting on the PHS interface (10-11 km depths), rather than on a mega-splay fault (8-9 km depths).

To provide additional constraints of the centroid depth of the 2016 SE offshore Mie earthquake, we compared the spatial distributions of simulated and observed first-motion polarizations at Hi-net/F-net and DONET stations. Figure 10 shows the distributions of first-motion polarizations from the observations and simulations of the MT results at depths of 8,11 , and $14 \mathrm{~km}$. Stations with incorrect polarity are enhanced by purple circles. The MT solutions for the two shallower depths (8 and $11 \mathrm{~km}$ ) correspond to ruptures occurring on the mega-splay fault and PHS interface, respectively. The optimal MT result at a depth of $11 \mathrm{~km}$ well reproduces the observed first-motion polarizations except 


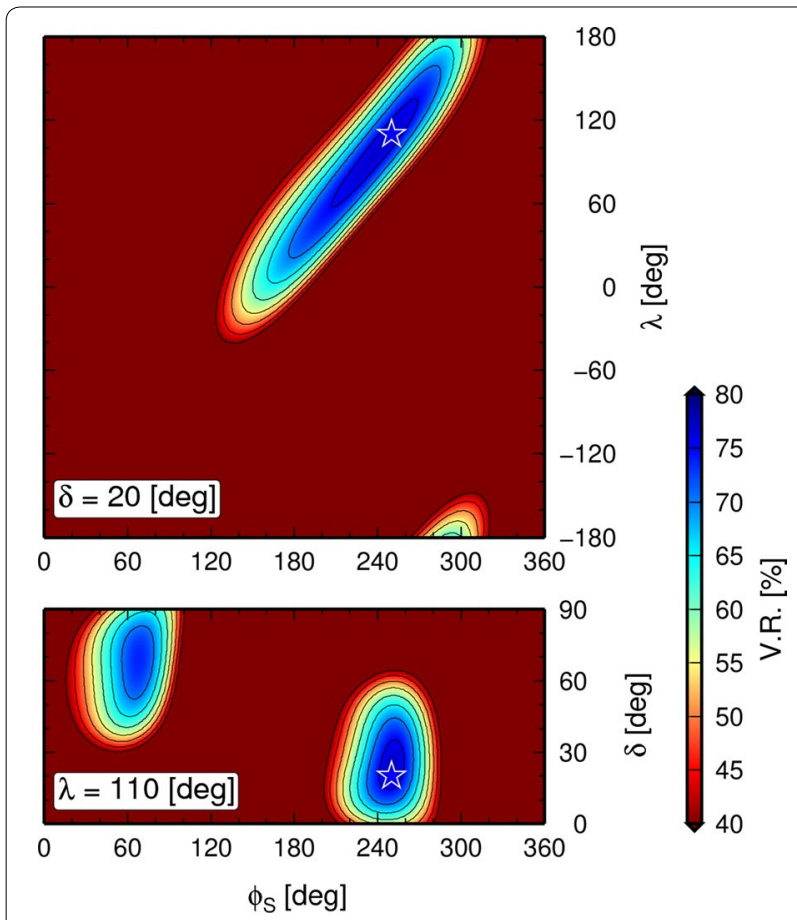

Fig. 9 Distribution of the variance reduction (V.R.) in the strike-rake $\left(\varphi_{S}-\lambda\right)$ and strike-dip $\left(\varphi_{S}-\delta\right)$ planes. Variance reductions were evaluated by using observed and synthetic F-net displacement waveforms for periods of 30-100 s. Synthetic waveforms were calculated for various focal mechanisms with a fixed centroid depth and seismic moment. White stars indicate the best-fit double-couple model of our MT results for the 2016 SE offshore Mie earthquake

for three DONET stations just above the hypocenter (lower-left subfigure of Fig. 10). If we employ the MT solution near the mega-splay fault $(8 \mathrm{~km})$, discrepancies of first-motion polarizations appear at land-area stations (upper-right subfigure of Fig. 10). The MT solution with a $14 \mathrm{~km}$ depth, which also shows higher variance reduction (77\%) and suggests an intra-slab earthquake, has discrepancies at not only the stations just above the hypocenter, but also those relatively far away (lowerright subfigure of Fig. 10). The number of stations with an incorrect polarity was the smallest for the MT solution with $11 \mathrm{~km}$ depth.

According to the MT inversion and first-motion analysis using a local 3D velocity structure model, we confirmed that the 2016 SE offshore Mie earthquake was characterized by a low-angle thrust earthquake occurred at a depth of $11 \mathrm{~km}$, near the PHS interface. Simulated vertical $P$ waveforms using our MT solution agreed well with the observations (Additional file 1: Figure S4b). The MT result of $14 \mathrm{~km}$ depth reproduced both apparent velocities and first-motion polarizations along profile A-B only (Additional file 1: Figure S4c). A crustal phase of $P$ waves was found in the MT solution with $14 \mathrm{~km}$ depth (blue line in Additional file 1: Figure S4c).

\section{Seismicity around the Tonankai Region}

Figure 11 shows our MT results and the hypocenter distributions around the epicenter region from catalogs of JMA and Wallace et al. (2016). Wallace et al. (2016) analyzed the earthquakes occurred on April 1-2, 2016 by using continuous DONET records. They also suggested that the rupture of the 2016 SE offshore Mie earthquake and subsequent aftershocks occurred on the PHS interface. Spatial patterns of first-motion polarizations and traveltimes during an aftershock (Additional file 1: Figure S5), which were similar to the 2016 SE offshore Mie earthquake, support their interpretation for aftershocks. The earthquakes occurred after the 2016 SE offshore Mie earthquake may have similar hypocenter depths and focal mechanisms.

In the Nankai subduction zone, the blue shaded area in Fig. 11 has accumulated a slip deficit of approximately 3-4 cm per year (e.g., Yokota et al. 2016). However, regular earthquakes near the PHS interface were not listed in the JMA catalog (circles in Fig. 11). Hypocenter determination for the 2011-2013 earthquakes using both DONET and land-area seismic observations and a 3D velocity structure model also detected no inter-plate earthquakes near the rupture area of the 1944 Tonankai earthquake (Figs. 7 and 11 of Nakano et al. 2015). Thus, a large amount of slip deficit, which may cause large tsunamigenic earthquakes, is expected around the region. The sudden sequence of thrust faulting earthquakes including the 2016 offshore Mie earthquake was concentrated in a narrow region, which is located at the shallower edge of the rupture area of the 1944 and the expected Tonankai earthquake (blue shaded area in the upper-right subfigure). Recent studies reported migration of regular earthquakes toward the hypocenter of large earthquakes in the subduction zones (e.g., Kato et al. 2012, 2016; Kubota et al. 2017a). Kato et al. (2012) interpreted the inter-plate foreshock migration before the 2011 Tohoku earthquake as propagation of slow slip. A slow slip event and episodic tremors near the trench were also detected after the 2016 SE offshore Mie earthquake (Annoura et al. 2017; Araki et al. 2017).

To discuss relations between regular earthquakes and slow slip, precise estimations of earthquake source parameters, especially the dip angle and depth, are important. Conventional analysis using a 1D model provided an incorrect depth and focal mechanism of the MT solution (this study) and first-motion solution (Takemura et al. 2016) for the shallow offshore earthquakes, suggesting intra-slab earthquake. Analyses and developments of methods including full 3D models, which can determine 


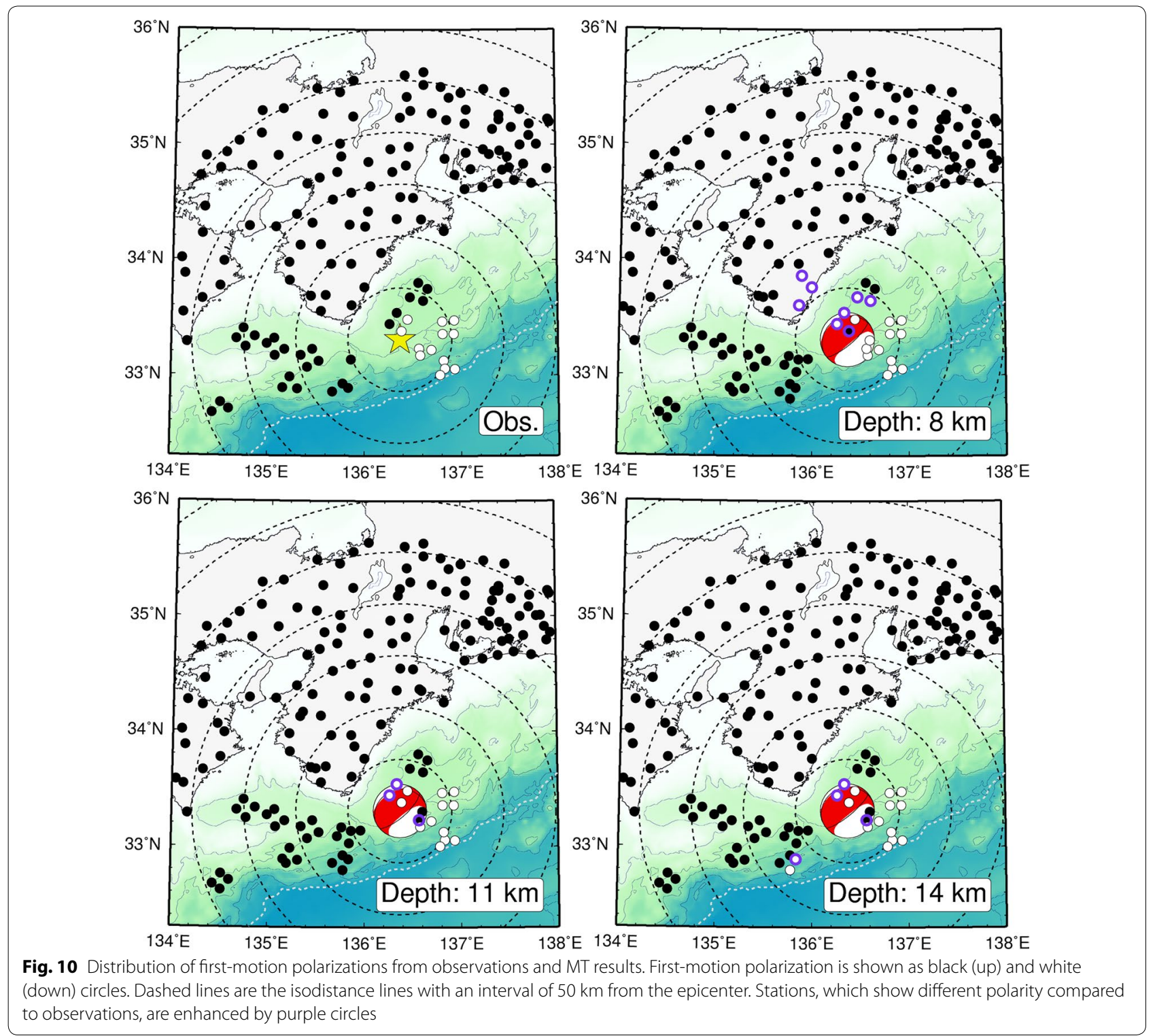

earthquakes occurred on the plate interface or within the plate, are important.

\section{Broadband seismic wave propagation during the 2016 offshore Mie earthquake}

Figure 12 shows the three-component filtered velocity seismograms for periods of 5-100 s at F-net stations; this is a broader period range compared to our MT analysis, and it includes dominant periods of strong long-period ground motions within the large sedimentary basins (e.g., Miyake and Koketsu 2005; Furumura et al. 2008; Yoshimoto and Takemura 2014; Yoshimoto et al. 2016). In the radial and vertical components, synthetic waveforms correspond to the observed ones. Amplitudes and group velocity of the crustal Rayleigh waves were roughly reproduced by the simulations of our MT solution in the JIVSM. However, the simulated waveforms of the transverse component (Love waves) did not successfully correspond to the observed ones. High sensitivities of Love waves for periods less than $20 \mathrm{~s}$ appeared at shallower $(<10 \mathrm{~km})$ depths (e.g., Fig. 12 of Nishida et al. 2008). Eigenfunctions of Love waves for period less than $30 \mathrm{~s}$ were trapped within the accretionary prism (Additional file 1: Figure S1). Thus, the waveform comparisons (Fig. 12) suggest that shallower structures within the JIVSM accretionary prism are insufficient to reproduce the observed propagations of seismic waves for periods less than $30 \mathrm{~s}$. Guo et al. (2016) numerically 


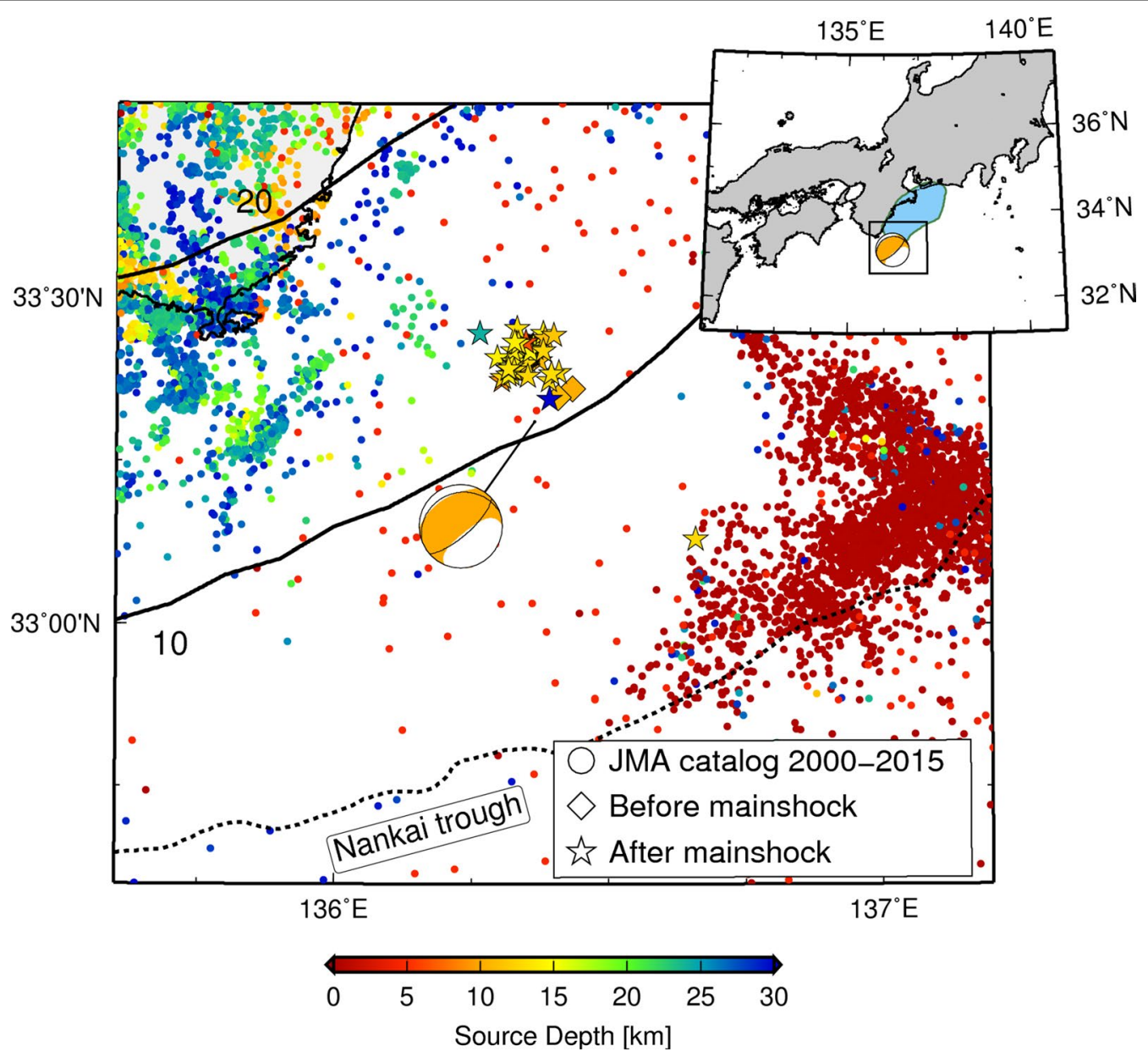

Fig. 11 Seismic activity in the SE offshore Mie region. Circles are referred from the JMA unified catalog. Diamonds and stars are earthquakes that occurred on 1-2 April around the epicenter region, and these were determined via traveltime analysis by Wallace et al. (2016). Diamonds and stars denote earthquakes before and after the 2016 SE offshore Mie earthquake, respectively. The color of each symbol represents the hypocenter depth of each event. The plotted focal sphere represents our MT result of the 2016 SE offshore Mie earthquake. Isodepth lines of the upper surface of the Philippine Sea plate are shown at 10-km intervals (Baba et al. 2002; Hirose et al. 2008). The blue shaded area in the upper-right subfigure represents the expected source region of the Tonankai earthquake

demonstrated the influence of shallower $S$-wave structures within the accretionary prism on evaluations of strong long-period ground motions. To achieve more practical evaluations of strong and long-period ground motions for future large earthquakes, $S$-wave velocity structures within the accretionary prism should be further improved. Such improved information would also enable us to conduct MT inversions using seismograms with shorter-period components for not only moderateto-large but also small $(M>4)$ earthquakes.

\section{Conclusions}

We conducted a 3D MT inversion of the 2016 SE offshore Mie earthquake, which occurred near the source region of the 1944 Tonankai earthquake (M7.9), by using long-period (30-100 s) displacement seismograms of regional seismic networks. By using synthetic seismograms in a full 3D model, we demonstrated the effects of offshore heterogeneities, such as the subducting oceanic plate and low-velocity layers (accretionary prism and seawater), on the MT inversion of offshore earthquakes in subduction zones. If simpler models without the subducting oceanic plate or low-velocity layers were employed, the centroid depth and focal mechanism were not well estimated. Similar values of variance reductions appeared irrespective of depths. Particularly, conventional $1 \mathrm{D}$ analysis provided a solution with a higher dipping angle compared to the assumed one. Thus, the use of a full 3D model including such heterogeneities as described above is necessary to provide depth and dip 


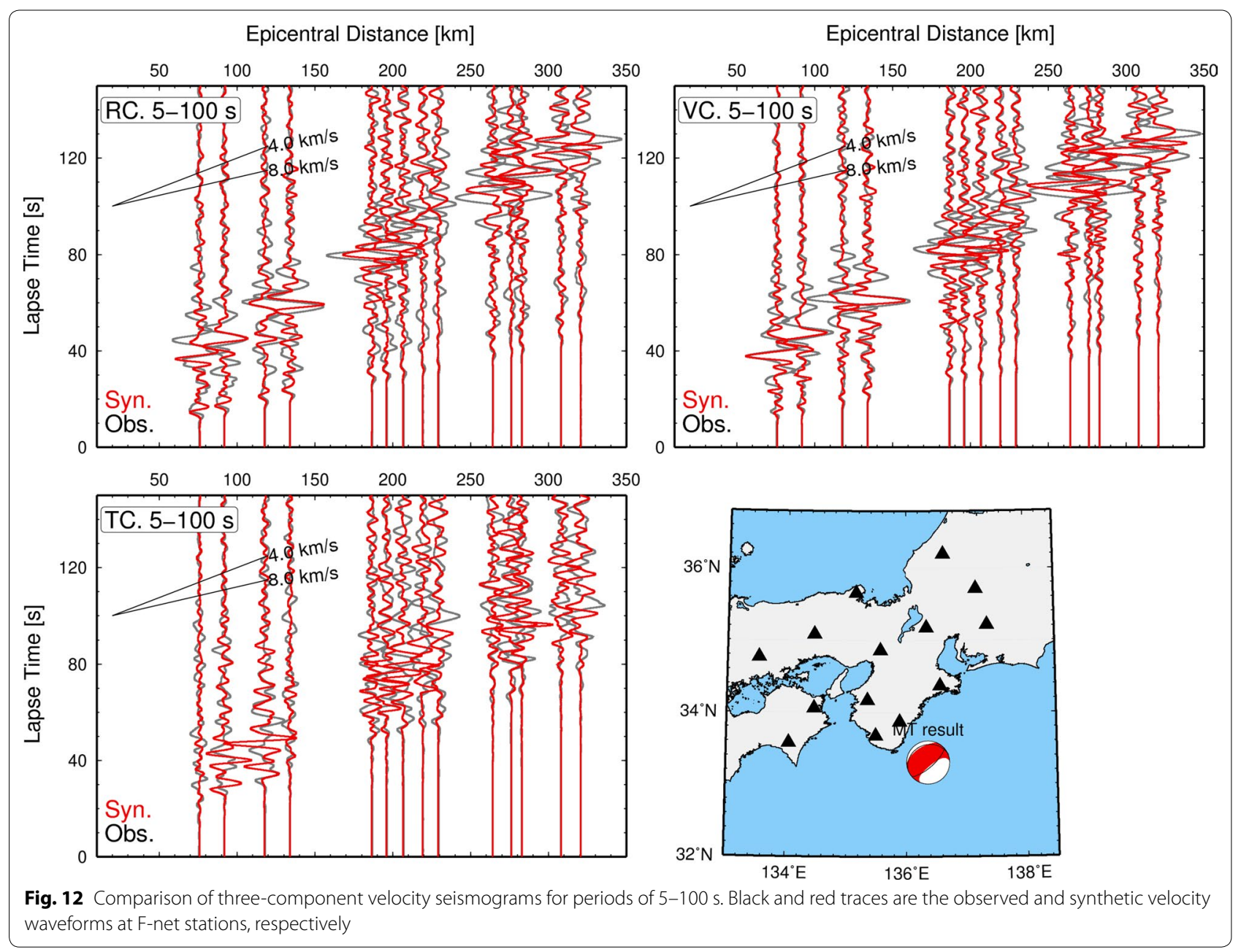

angle constraints for offshore earthquakes in the subduction zone. Excitations and propagations of surface waves are mostly controlled by low-velocity layers just above the hypocenter even for long periods (30-100 s). Particularly, to achieve better fitting of observed long-period displacement waveforms, the accretionary prism should be taken into account in the model.

According to the MT inversion using observed longperiod displacements, the 2016 SE offshore Mie earthquake was characterized by a low-angle thrust faulting mechanism at a depth of $11 \mathrm{~km}$, while the F-net MT solution of this earthquake showed a reverse faulting mechanism with a dip angle of $38^{\circ}$ and a depth of $14 \mathrm{~km}$. Our result has a similar focal mechanism but shallower depth compared to the ones from the global catalog. By comparisons with seismic surveys in the Tonankai region, this earthquake could be interpreted as a rupture on the PHS interface, rather than on a mega-splay fault. First-motion analysis using a local 3D velocity structure model provided additional constraints of the centroid depth, and results suggest that the rupture of the 2016 SE offshore Mie earthquake occurred on the PHS interface. Simulations of strong long-period ground motions using our MT solution for periods below $5 \mathrm{~s}$ practically reproduced the observed waveforms.

DONET, which provides ocean area seismic observation records, has been in operation since 2010 and observation data are still limited compared to the landarea networks Hi-net and F-net. Our knowledge of the characteristics of ocean bottom seismograms is also still limited, although a few pioneering studies have been conducted (e.g., Nakamura et al. 2015; Dhakal et al. 2016). Our experiments demonstrated that MT inversion using a 3D model can provide precise estimation of the focal mechanisms and depths of offshore earthquakes even if land-area observation data are only available. However, the computational costs of evaluations of 3D Green's functions for large number source grids are still expensive even if we employ longer grid intervals for evaluating long-period (>10 s) displacements only. To achieve 
practical 3D monitoring of offshore earthquakes, which include shallow very low-frequency events near the trench, more sophisticated methods, e.g., reciprocal calculations (e.g., Okamoto 2002; Petukhin et al. 2016; Hejrani et al. 2017; Maeda et al. 2017), will be useful. Due to reduction of computational costs via reciprocal calculation, Green's functions could be pre-calculated at the many assumed source grids. Pre-calculated catalogs of Green's functions would allow us to conduct practical MT inversions of many earthquakes, finite source modeling, and high-frequency waveform modeling (e.g., Graves and Wald 2001; Furumura and Kennett 2005; Petukhin et al. 2016; Hejrani et al. 2017). These technical developments will also provide opportunities for model improvements of the subsurface structure for precise ground motion evaluations.

\section{Additional files}

Additional file 1: Figure S1. shows the results of 1D analysis for effects of accretionary prism on Love wave propagation. Waveform fittings of MT result of the 2016 SE offshore Mie earthquake using sJIVSM are illustrated in Figure S2. FigureS3 shows estimated focal mechanism via additional MT inversions using the JIVSM with $\pm 0.1^{\circ}$ source grids. Figure $\mathbf{S 4}$ iscomparison of $P$ wave propagation between observation and simulations. Figure $\mathbf{S 5}$ is traveltimes and polarizations offirst-arrival $P$ waves of M3 aftershock.

\section{Abbreviations}

1D: one-dimensional; 3D: three-dimensional; FDM: finite-difference method; F-net: full-range seismograph network; GCMT: global centroid moment tensor; Hi-net: high-sensitivity seismograph network; ISC-GEM: International Seismological Centre-Global Earthquake Model; JAMSTEC: Japan Agency for Marine-Earth Science and Technology; JVVSM: Japan Integrated Velocity Structure Model; JMA: Japan Meteorological Agency; MT: moment tensor; NIED: National Research Institute for Earth Science and Disaster Resilience; PHS: Philippine Sea plate; SE: Southeast; SJVSM: simplified JIVSM; $V_{p}: P$-wave velocity; V.R.: variance reduction; $V_{S}$ : $S$-wave velocity.

\section{Authors' contributions}

ST conducted the waveform analysis for both observations and simulations and drafted this manuscript. TK, HK, and KS participated in the study design and interpretation of the results. TS participated in the considerations for wave propagation. All authors read and approved the final manuscript.

\section{Acknowledgements}

The Hi-net, F-net, and DONET waveform data and the F-net MT solutions were provided by the National Research Institute for Earth Science and Disaster Resilience (NIED), Japan, via the institute's website (http://www.hinet.bosai. go.jp/). We also used the unified hypocenter catalog (http://www.data.jma. go.jp/svd/eqev/data/bulletin/index.html) provided by the Japan Meteorological Agency and GCMT catalog (Ekström et al. 2012; http://www.globalcmt. org/CMTsearch.html). Bathymetric depth data were obtained from ETOPO1 (Amante and Eakins 2009; http://www.ngdc.noaa.gov/mgg/global/global. html). The software for sensor response correction by Maeda et al. (2011) is available via Dr. T. Maeda's website (http://github.com/takuto-maeda/ hinet_decon/releases). The 3D layered structure of the JIVSM is available via the Japanese website (http://www.jishin.go.jp/main/chousa/12_choshuki/ dat/). Depth data for the upper surface of the Philippine Sea plate are available via Dr. F. Hirose's website (http://www.mri-jma.go.jp/Dep/st/member/fhirose/ ja/PlateData.html). Generic Mapping Tools (Wessel and Smith 1998) was used to prepare the figures. The FDM simulations were conducted on the Earth
Simulator at the Japan Agency for Marine-Earth Science and Technology. We also thank two anonymous reviewers and the editor Prof. J. Nakajima for careful reviewing and constructive comments, which have helped improve the manuscript.

\section{Competing interests}

The authors declare that they have no competing interests.

\section{Availability of data and materials}

The data that support the results in the manuscript are available from the corresponding author ST on request.

\section{Consent for publication \\ Not applicable.}

\section{Ethics approval and consent to participate}

Not applicable.

\section{Funding}

This study was supported by the Tokyo Marine Kagami Memorial Foundation, a Grant-in-Aid for Seismology, the Grants-in-Aid program of the Japan Society for the Promotion of Science (\#17K14382), and by a collaborative research program of the Earthquake Research Institute, the University of Tokyo (\#2015-B-01).

\section{Publisher's Note}

Springer Nature remains neutral with regard to jurisdictional claims in published maps and institutional affiliations.

Received: 14 December 2017 Accepted: 15 March 2018

Published online: 23 March 2018

\section{References}

Aki K, Richards P (2002) Quantitative seismology, 2nd edn. University Science Books, Freeman, San Francisco

Amante C, Eakins BW (2009) ETOPO1 Arc-minute global relief model: procedure, data sources and analysis: NOAA technical memorandum NESDIS NGDC-24. National Geophysical Data Center, NOAA. https://doi. org/10.7289/v5c8276m

Ando M (1975) Source mechanisms and tectonic significance of historical earthquakes along the Nankai Trough, Japan. Tectonophysics 27(2):119140. https://doi.org/10.1016/0040-1951(75)90102-X

Annoura S, Hashimoto T, Kamaya N, Katsumata A (2017) Shallow episodic tremor near the Nankai Trough axis off southeast Mie prefecture, Japan. Geophys Res Lett 44:3564-3571. https://doi. org/10.1002/2017GL073006

Araki E, Saffer DM, Kopf AJ, Wallace LM, Kimura T, Machida Y, Ide S, Davis E, IODP Expedition 365 shipboard scientists (2017) Recurring and triggered slow-slip events near the trench at the Nankai subduction megathrust. Science 356:1157-1160. https://doi.org/10.1126/science.aan3120

Baba T, Tanioka Y, Cummins PR, Uhira K (2002) The slip distribution of the 1946 Nankai earthquake estimated from tsunami inversion using a new plate model. Phys Earth Planet Inter 132(1):59-73. https://doi.org/10.1016/ S0031-9201(02)00044-4

Dhakal YP, Aoi S, Kunugi T, Suzuki W, Kimura T (2016) Assessment of nonlinear site response at ocean bottom seismograph sites based on S-wave horizontal-to-vertical spectral ratios: a study at the Sagami Bay area K-NET sites in Japan. Earth Planets Space 69:29. https://doi.org/10.1186/ s40623-017-0615-5

Ekström G, Nettles M, Dziewoński AM (2012) The global CMT project 20042010: centroid-moment tensors for 13,017 earthquakes. Phys Earth Planet Inter 200-201:1-9. https://doi.org/10.1016/j.pepi.2012.04.002

Fukao Y (1979) Tsunami earthquakes and subduction processes near deepsea trenches. J Geophys Res 84:2303-2314. https://doi.org/10.1029/ JB084iB05p02303

Fukuyama E, Ishida M, Dreger DS, Kawai H (1998) Automated seismic moment tensor determination by using on-line broadband seismic waveforms. 
Zisin 51:149-156. https://doi.org/10.4294/zisin1948.51.1_149 (in Japanese with English abstract)

Furumura T, Chen L (2004) Large scale parallel simulation and visualization of 3D seismic wavefield using Earth simulator. Comput Model Eng Sci 6:153-168. https://doi.org/10.3970/cmes.2004.006.153

Furumura T, Kennett BLN (2001) Variations in regional phase propagation in the area around Japan. Bull Seismol Soc Am 91:667-682

Furumura T, Kennett BLN (2005) Subduction zone guided wave and the heterogeneity structure of the subducted plate: intensity anomalies in northern Japan. J Geophys Res 100:B10302. https://doi. org/10.1029/2004JB003486

Furumura T, Hayakawa T, Nakamura M, Koketsu K, Baba T (2008) Development of long-period ground motions from the Nankai Trough, Japan, earthquake: observations and computer simulation of the 1944 Tonankai (Mw 8.1) and the 2004 SE Off-Kii Peninsula (Mw 7.4) earthquakes. Pure appl Geophys 165:585-607. https://doi.org/10.1007/s00024-008-0318-8

Graves RW, Wald DJ (2001) Resolution analysis of finite source inversion using one- and three-dimensional Green's functions: 1. Strong motions. J Geophys Res 106:8745-8766. https://doi.org/10.1029/2000JB900436

Guo Y, Koketsu K, Miyake H (2016) Propagation mechanism of long-period ground motions for offshore earthquakes along the Nankai Trough: effects of accretionary wedge. Bull Seismol Soc Am 106:1176-1197. https://doi.org/10.1785/0120150315

Hayakawa T, Furumura T, Yamanaka Y (2005) Simulation of strong ground motions caused by the 2004 off the Kii peninsula earthquakes. Earth Planets Space 57:191-196. https://doi.org/10.1186/BF03351814

Hejrani B, Tkalčić H, Fichtner A (2017) Centroid moment tensor catalogue using a 3-D continental scale Earth model: application to earthquakes in Papua New Guinea and the Solomon Islands. J Geophys Res 122:55175543. https://doi.org/10.1002/2017JB014230

Heki K, Miyazaki S (2001) Plate convergence and long-term crustal deformation in central Japan. Geophys Res Lett 28:2313-2316. https://doi. org/10.1029/2000GL012537

Herrmann RB (2013) Computer programs in seismology: an evolving tool for instruction and research. Seismol Res Lett 84:1081-1088. https://doi. org/10.1785/0220110096

Hingee M, Tkalčić H, Fichtner A, Sambridge M (2011) Seismic moment tensor inversion using a 3-D structural mode: applications for the Australian region. Geophys J Int 184:949-964. https://doi. org/10.1111/j.1365-246X.2010.04897.X

Hirose F, Nakajima J, Hasegawa A (2008) Three-dimensional seismic velocity structure and configuration of the Philippine Sea slab in southwestern Japan estimated by double-difference tomography. J Geophys Res 133:B09315. https://doi.org/10.1029/2007JB005274

Hok S, Fukuyama E, Hashimoto C (2011) Dynamic rupture scenarios of anticipated Nanka-Tonankai earthquakes, southwest Japan. J Geophys Res 116:B12319. https://doi.org/10.1029/2011JB008492

Hori T, Kato N, Hirahara K, Baba T, Kaneda Y (2004) A numerical simulation of earthquake cycles along the Nankai Trough in southwest Japan: lateral variation in frictional property due to the slab geometry controls the nucleation position. Earth Planet Sci Lett 228:215-226. https://doi. org/10.1016/j.epsl.2004.09.033

Hyodo M, Hori T, Ando K, Baba T (2014) The possibility of deeper or shallower extent of the source area of Nankai Trough earthquakes based on the 1707 Hoei tsunami heights along the Pacific and Seto Island Sea coasts, southwest Japan. Earth Planets Space 66:123. https://doi. org/10.1186/1880-5981-66-123

Ji C, Helmberger DV, Wald DJ, Ma KF (2003) Slip history and dynamic implications of the 1999 Chi-Chi, Taiwan, earthquake. J Geophys Res 108:2412. https://doi.org/10.1029/2002JB001764

Kaneda Y, Kawaguchi K, Araki E, Matsumoto H, Nakamura T, Kamiya S, Ariyoshi K, Hori T, Baba T, Takahashi N (2015) Development and application of an advanced ocean floor network system for megathrust earthquakes and tsunamis. In: Favali P et al. (eds) Seafloor observatories. Springer, Berlin, pp 643-662. https://doi.org/10.1007/978-3-642-11374-1_25

Kato A, Obara K, Igarashi T, Tsuruoka H, Nakagawa S, Hirata N (2012) Propagation of slow slip leading up to the $2011 \mathrm{Mw}$ 9.0 Tohoku-oki earthquake. Science 335:705. https://doi.org/10.1126/science.1215141

Kato A, Fukuda J, Kumazawa T, Nakagawa S (2016) Accelerated nucleation of the 2014 Iquique, Chile Mw 8.2 earthquake. Sci Rep 6:24792. https://doi. org/10.1038/srep24792
Kawaguchi K, Kaneko S, Nishida T, Komine T (2015) Construction of the DONET real-time seafloor observatory for earthquakes and tsunami monitoring. In: Favali P et al. (eds) Seafloor observatories. Springer, Berlin, pp 211-228. https://doi.org/10.1007/978-3-642-11374-1_10

Kikuchi M, Kanamori H (1991) Inversion of complex body waves-III. Bull Seismol Res Am 81:2335-2350

Kikuchi M, Nakamura M, Yoshikawa K (2003) Source rupture processes of the 1944 Tonankai earthquake and the 1945 Mikawa earthquake derived from low-gain seismograms. Earth Planets Space 55:BF03351745. https:// doi.org/10.1186/bf0335175

Kim S, Saito T, Fukuyama E, Kang TS (2016) The Nankai Trough earthquake tsunami in Korea: numerical studies of the 1707 Hoei earthquake and physics-based scenario. Earth Planets Space 68:64. https://doi. org/10.1186/s40623-016-0438-9

Koketsu K, Yokota Y, Nishimura N, Yagi Y, Miyazaki S, Satake K, Fujii Y, Miyake H, Sakai S, Yamanaka Y, Okada T (2011) A unified source model for the 2011 Tohoku earthquake. Earth Planet Sci Lett 310(3):480-487. https://doi. org/10.1016/j.epsl.2011.09.009

Koketsu K, Miyake H, Suzuki H (2012) Japan integrated velocity structure model version 1. In: Proceedings of the 15th world conference on earthquake engineering, Lisbon, Portugal, 24-28 Sept

Kubo A, Fukuyama E, Kawai H, Nonomura K (2002) NIED seismic moment tensor catalogue for regional earthquakes around Japan: quality test and application. Tectonophysics 356:23-48. https://doi.org/10.1016/ S0040-195(02)00375-X

Kubota T, Hino R, Inazu D, Ito Y, linuma T, Ohta Y, Suzuki S, Suzuki K (2017a) Coseismic slip model of offshore moderate interplate earthquakes on March 9, 2011 in Tohoku using tsunami waveforms. Earth Planet Sci Lett 458:241-251. https://doi.org/10.1016/j.epsl.2016.10.047

Kubota T, Saito T, Suzuki W, Hino R (2017b) Estimation of seismic centroid moment tensor using ocean bottom pressure gauges as seismometers. Geophys Res Lett 44:10907-10915. https://doi. org/10.1002/2017GL075386

Kuge K (2003) Source modeling using strong motion waveforms: toward automated determination of earthquake fault planes and momentrelease distributions. Bull Seismol Soc Am 93:639-654. https://doi. org/10.1785/0120020076

Lee SJ, Huang BS, Liang WT, Chen KC (2010) Grid-based moment tensor inversion technique by using 3-D Green's functions database: a demonstration of the 23 October 2004 Taipei earthquake. Terr Atoms Ocean Sci 21:503-514. https://doi.org/10.3319/TAO.2010.01.25.02(TH)

Liu Q, Polet J, Komatitsch D, Tromp J (2004) Spectral-element moment tensor inversions for earthquakes in southern California. Bull Seismol Soc Am 94:1748-1761. https://doi.org/10.1785/012004038

Maeda T, Obara K, Furumura T, Saito T (2011) Interference of long-period seismic wavefield observed by the dense Hi-net array in Japan. J Geophys Res 116:B10303. https://doi.org/10.1029/JB008464

Maeda T, Furumura T, Obara K (2014) Scattering of teleseismic P-waves by the Japan Trench: a significant effect of reverberation in the seawater column. Earth Planet Sci Lett 397:101-110. https://doi.org/10.1016/j. epsl.2014.04.037

Maeda T, Takemura S, Furumura T (2017) OpenSWPC: an open-source integrated parallel simulation code for modeling seismic wave propagation in 3D heterogeneous viscoelastic media. Earth Planets Space 69:102. https://doi.org/10.1186/s40623-017-0687-2

Miyake H, Koketsu K (2005) Long-period ground motions from a large offshore earthquake: the case of the 2004 off the Kii peninsula earthquake, Japan. Earth Planets Space 57:203. https://doi.org/10.1186/BF03351816

Miyazawa M (2016) An investigation into the remote triggering of the Oita earthquake by the $2016 \mathrm{Mw} 7.0$ Kumamoto earthquake using full wavefield simulation. Earth Planets Space 66:205. https://doi.org/10.1186/ s40623-016-0585-z

Nakamura T, Takenaka H, Okamoto T, Ohori M, Tsuboi S (2015) Long-period ocean-bottom motions in the source areas of large subduction earthquakes. Sci Rep 5:16648. https://doi.org/10.1038/srep16648

Nakano M, Nakamura T, Kaneda Y (2015) Hypocenters in the Nankai Trough determined by using data from both ocean-bottom and land seismic networks and a 3D velocity structure model: implications for seismotectonic activity. Bull Seismol Soc Am 105:1594-1605. https://doi. org/10.1785/0120140309 
Nishida K, Kawakatsu H, Obara K (2008) Three-dimensional crustal S wave velocity structure in Japan using microseismic data recroded by Hi-net tiltmeters. J Geophys Res 113:B10302. https://doi. org/10.1029/2007JB005395

Noguchi S, Maeda T, Furumura T (2016) Ocean-influenced Rayleigh waves from outer-rise earthquakes and their effects on durations of long-period ground motion. Geophys J Int 205:1099-1107. https://doi.org/10.1093/ gji/ggw074

Okada Y, Kasahara K, Hori S, Obara K, Sekiguchi S, Fujiwara H, Yamamoto A (2004) Recent progress of seismic observation networks in Japan-Hi-net, F-net, K-NET and KiK-net. Earth Planets Space 56(8):xv-Xxviii. https://doi. org/10.1186/bf03353076

Okamoto T (2002) Full waveform moment tensor inversion by reciprocal finite difference Green's function. Earth Planets Space 54:715-720. https://doi. org/10.1186/BF03351723

Park JO, Tsuru T, Kodaira S, Cummins PR, Kaneda Y (2002) Splay fault branching along the Nankai subduction zone. Science 297:1157-1160. https://doi. org/10.1126/science.1074111

Petukhin A, Miyakoshi K, Tsurugi M, Kawase H, Kamae K (2016) Visualization of Green's function anomalies for megathrust source in Nankai Trough by reciprocity method. Earth Planets Space 68:4. https://doi.org/10.1186/ s40623-016-0385-5

Ramos-Martínez J, McMechan GA (2001) Source-parameter estimation by ful waveform inversion 3-D heterogeneous, viscoelastic, anisotropic media. Bull Seismol Soc Am 91:276-291. https://doi.org/10.1785/0120000017

Seno T, Stein S, Gripp AE (1993) A model for the motion of the Philippine Sea plate consistent with NUVEL-1 and geophysical data. J Geophys Res 98:17941-17948. https://doi.org/10.1029/93JB00782

Shapiro NM, Olsen KB, Singh K (2002) On the duration of seismic incident onto the Valley of Mexico for subduction zone earthquake. Geophys J Int 151:501-510. https://doi.org/10.1046/j.1365-246X.2002.01789.x

Sokos EN, Zahradnik J (2008) ISOLA a Fortran code and a Matlab GUI to perform multiple-point source inversion of seismic data. Comput Geosci 34:967-977. https://doi.org/10.1016/j.cageo.2007.07.005

Storchak DA, Giacomo DD, Bondár I, Engdahl ER, Harris J, Lee WHK, Villaseñor A, Bormann P (2013) Public release of the ISC-GEM Global instrumental earthquake catalogue. Seismol Res Lett 84:810-815. https://doi. org/10.1785/02200130034

Sugioka H, Okamoto T, Nakamura T, Ishihara Y, Ito A, Obana K, Kinoshita M, Nakahigasi K, Shinohara M, Fukao Y (2012) Tsunamigenic potential of the shallow subduction plate boundary inferred from slow seismic slip. Nat Geosci 5:414-418. https://doi.org/10.1038/ngeo1466

Takemura S, Furumura T, Maeda T (2015a) Scattering of high-frequency seismic waves caused by irregular surface topography and small-scale velocity inhomogeneity. Geophys J Int 201(1):459-474. https://doi.org/10.1093/ gji/ggv038

Takemura S, Akatsu M, Masuda K, Kajikawa K, Yoshimoto K (2015b) Longperiod ground motions in a laterally inhomogeneous large sedimentary basin: observations and model simulations of long-period surface waves in the northern Kanto Basin, Japan. Earth Planets Space 67:33. https://doi. org/10.1186/s40623-015-0201-7

Takemura S, Yoshimoto K, Tonegawa T (2015c) Scattering of trapped P and $S$ waves in the hydrated subducting crust of the Philippine Sea plate at shallow depths beneath the Kanto region, Japan. Geophys J Int 203:2261-2276. https://doi.org/10.1093/gji/ggv423

Takemura S, Shiomi K, Kimura T, Saito T (2016) Systematic difference between first-motion and waveform-inversion solutions for shallow offshore earthquakes due to a low-angle dipping slab. Earth Planets Space 68:149. https://doi.org/10.1186/s40623-016-0527-9

Takemura S, Kobayashi M, Yoshimoto K (2017) High-frequency seismic wave propagation within the heterogeneous crust: effects of seismic scattering and intrinsic attenuation on ground motion modelling. Geophys J Int 210:1806-1822. https://doi.org/10.1093/gji/ggx269

Todoriki M, Furumura T, Maeda T (2017) Effects of sea water on elongated duration of ground motion as well as variation in its amplitude for offshore earthquakes. Geophys J Int 208:226-233. https://doi.org/10.1093/ gji/ggw388

Tsuji T, Kamei R, Pratt PG (2014) Pore pressure distribution of a mega-splay fault system in the Nankai Trough subduction zone: insight into up-dip extent of the seismogenic zone. Earth Planet Sci Lett 396:165-178. https://doi. org/10.1016/j.epsl.2014.04.011

Tsuruoka H, Kawakatsu H, Urabe T (2009) GRiD MT (grid-based real-time determination of moment tensors) monitoring the long-period seismic wavefield. Phys Earth Planet Inter 175:8-16. https://doi.org/10.1016/j. pepi.2008.02.014

Wallace LM, Araki E, Saffer D, Wang X, Roesner A, Kopf A, Nakanishi A, Power W, Kobayashi R, Kinoshita C, Toczko S, Kimura T, Machida Y, Carr S (2016) Near-field observations of an offshore Mw 6.0 earthquake from an integrated seafloor and subseafloor monitoring network at the Nankai Trough, southwest Japan. J Geophys Res 121:8338-8351. https://doi. org/10.1002/2016JB013417

Wessel P, Smith WHF (1998) New, improved version of generic mapping tools released. EOS Trans Am Geophys Union 79(47):579. https://doi. org/10.1029/98EO00426

Yokota Y, Ishikawa T, Watanabe S, Tashiro T, Asada A (2016) Seafloor geodetic constraints on interplate coupling of the Nankai Trough megathrust zone. Nature 534:374-377. https://doi.org/10.1038/nature17632

Yoshimoto K, Takemura S (2014) A study on the predominant period of longperiod ground motions in the Kanto Basin, Japan. Earth Planets Space 66:100. https://doi.org/10.1186/1880-5981-66-100

Yoshimoto K, Kajikawa K, Masuda K, Takemura S (2016) Elongation of the dominant period of long-period ground motions in the Tokyo bay area. In: Proceedings of the 11 th Asian seismological commission general assembly, Melbourne, Australia, 25-27 Nov

Zhu L, Helmberger DV (1996) Advancement in source estimation techniques using broadband regional seismograms. Bull Seismol Soc Am 86:1634-1641

\section{Submit your manuscript to a SpringerOpen ${ }^{\circ}$ journal and benefit from:}

- Convenient online submission

- Rigorous peer review

- Open access: articles freely available online

- High visibility within the field

Retaining the copyright to your article

Submit your next manuscript at springeropen.com 